\title{
Lapurdum
}

Euskal ikerketen aldizkaria | Revue d'études basques |

Revista de estudios vascos | Basque studies review

Numéro spécial 2 | 2015

Othoi çato etchera

\section{Le Dauphin itsasontziaren testuinguru historikoa : Louisbourgeko euskaldunak, ekonomia atlantiarra eta gerra (1713-1758)}

\section{Xabier Lamikiz}

\section{(2) OpenEdition}

1 Journals

\section{Édition électronique}

URL : https://journals.openedition.org/lapurdum/2546

DOI : 10.4000/lapurdum.2546

ISSN : 1965-0655

Éditeur

IKER

\section{Édition imprimée}

Date de publication : 1 octobre 2015

Pagination : $17-43$

ISBN : 978-2-9553413-7-5

ISSN : 1273-3830

\section{Référence électronique}

Xabier Lamikiz, «Le Dauphin itsasontziaren testuinguru historikoa : Louisbourgeko euskaldunak ekonomia atlantiarra eta gerra (1713-1758)», Lapurdum [Linean], Numéro spécial 2 | 2015, Sarean emana----an 01 septembre 2016, kontsultatu 02 avril 2023. URL: http://journals.openedition.org/ lapurdum/2546 ; DOI: https://doi.org/10.4000/lapurdum.2546

\section{(c) $($ ) $(9)$}

Creative Commons - Attribution-NonCommercial-NoDerivatives 4.0 International - CC BY-NC-ND 4.0 https://creativecommons.org/licenses/by-nc-nd/4.0/ 


\title{
Le Dauphin itsasontziaren testuinguru historikoa: Louisbourgeko euskaldunak, ekonomia atlantiarra eta gerra (1713-1758)
}

\author{
Xabier LAMIKIZ \\ UPV/EHU
}

\section{Le Dauphin itsasontzia}

1757ko apirilaren 9an Britainia Handiko hiru gerra-ontzik Atlantikoa zeharkatzen ari zen Le Dauphin zeritzon itsasontzi frantsesa harrapatu zuten. Baionatik atera eta Louisbourgerako norabidea zeraman Le Dauphin-ek. Britainiarrek itsasontzia ez ezik barnean zeraman guztia bahitu zuten, dokumentu mordoa barne. Dokumentuon artean euskaraz idatzitako 50 eskutitz zeuden, Lapurdiko 48 bizilagunek Louisbourg aldean zeuden 45 pertsonari bidaliak. ${ }^{1}$

Zazpi Urteko Gerraren (1756-1763) bigarren urtea zen eta Le Dauphin, merkataritza itsasontzia izateaz gain, kortsarioa ere bazen (edo, euskarazko eskutitzetan esaten den bezala, corsuzalea). Hori da hain zuzen britainiarrek enbargatutako paperen artean dagoen kortsu agiriak erakusten duena. Martin Lermet kapitain ziburutarrak ingelesei aitortuko zien bezala, ontziak "had a commission of war from the king of France". ${ }^{2}$ Kortsu agiriaren bidez (frantsesez lettre de marque edo lettre de course, gaztelaniaz patente de corso) merkatariek, eta bestelako enpresagizonek, gerra garaian euren errege edo herrialdearen etsaien aurka aritzeko baimena lortzen zuten. Gerrak itsas merkataritza gehiena eteten zuenez, kortsua dirua irabazteko jarduera erakargarri bihurtzen zen. Borrokatu ondoren harrapatua izanik, halaber, kortsu agiridun tripulazioak gerrako presoak bezala tratatuak izaten ziren, eta ez piratak bezala, eta ondorioz ez zuten urkamendian bukatzen.

Kortsu agiria zeraman arren, Le Dauphin-en eginkizun nagusia île Royale uharte frantsesera merkagaiak (ardoa, ehunak, arropa eta zapatak) eramatea zen. Ontziaren pleitatzailearen sinadura daramaten kontuen arabera, kargamentuaren balioa 17.568 liberakoa

1. Euskarazkoekin batera Le Dauphin-ek frantsesez idatzitako beste 107 eskutitz zeramatzan.

2. "Deposition of Martin Lermet", The National Archives (aurrerantzean TNA), High Court of Admiralty (aurrerantzean HCA) 32/180 (1). 
(livres tournois) zen, eta, horrez gain, ontzia gerrarako prestatzen beste 20.579 libera gastatu ziren Baionako portuan (horien artean 6.210 libera, tripulazioari aurretik ordaindutako hiru hilabeteko soldata). ${ }^{3}$ Aldi berean merkataritzan eta kortsuan aritzea oso ohikoa izan zen XVIII. mendeko gerra guztietan. David Starkey historialariak dioenez, hiru kortsu-ontzi mota izan ziren arruntenak: soilik kortsuan aritzen zirenak ("predatory cruising voyages"), gobernuaren berariazko aginduak zituztenak ("specialist vessels in government employment") eta, nagusiki merkataritzan jardun arren, kortsua bigarren eginkizun moduan zeukatenak ("armed trading vessels"). ${ }^{4}$ Le Dauphin azken mota horretakoa litzateke.

Le Dauphin-en eskifaikide kopurua da ontzia borrokarako prest zihoala erakusten duen beste froga ziur bat. XVIII. mendeko merkataritza itsasontzien jabeentzat oso garrantzitsua zen marinel kopuru egokia kontratatzea: gutxiegi baziren ontzia arriskuan jar zezaketen, eta gehiegi izanik, aldiz, jabeak soldatetan askotxo gastatu behar izaten zuen. Badakigu, Ralph Davis historialariaren lanari esker, mende erdialdean Ipar Atlantikoa zeharkatzen zuten ontziek zenbat eskifaikide behar izaten zituzten: 50-100 tona bitartekoek nahikoa zuten 1012 itsasgizonen lana. ${ }^{5}$ Le Dauphin 60 tonako ontzia zen (ingelesek zerabilten tona motaren arabera Baionako ontziak 80 tona zituen) eta, hala ere, 34 itsasgizon zeramatzan barruan, berez ontziak nabigatzeko beharko lituzkeenak baino askoz gehiago. 1. TAULAn ikus daitezke gizonon izen-abizenak, mailak, jaioterriak, adinak eta hileroko soldatak.

1. TaUla. Le Dauphin itsasontziko tripulazioa

\begin{tabular}{|l|c|c|c|c|}
\hline IZEN-ABIZENA & MAILA & JAIOTERRIA & ADINA & $\begin{array}{c}\text { HILEROKO } \\
\text { SOLDATA (liberatan) }\end{array}$ \\
\hline Ofizierak & & & & \\
\hline Martin Lermet & kapitaina & Ziburu & 26 & 160 \\
\hline Dominique Leblanc & 2. kapitaina & Louisbourg & 24 & 130 \\
\hline Pierre Derratsou & tenientea & Donibane Lohizune & 24 & 100 \\
\hline Jean Broutiere & entseinaria & Louisbourg & 20 & 70 \\
\hline Pierre Faurier & kirurgialaria & Argelos* & 37 & 75 \\
\hline Marinel ofizierak & & & & \\
\hline Joannis Lermet & kontramaisua & Ziburu & 47 & 90 \\
\hline Bicente Lissaratsou & 2. kontramaisua & Donibane Lohizune & 27 & 75 \\
\hline
\end{tabular}

3. "Doit le batteau Le Dauphin appartenant à M. de Laborde de Louisbourg s/c courant avec Jean Lanne de Bayonne", Baiona, 1757/4/4, TNA, HCA 32/180 (1).

4. StARKey, David J., 1990, British privateering enterprise in the eighteenth century, University of Exeter Press, Exeter, 51-52.

5. Davis, Ralph, 2012 [1962], The rise of the English shipping industry in the seventeenth and eighteent centuries, International Maritime Economic History Association, St. John's, Newfoundland, 70. 


\begin{tabular}{|c|c|c|c|c|}
\hline Bernard Hiriart & marinel ofiziera & Pon de Canot (?) & 27 & 70 \\
\hline Bernard Segar & kanoien arduraduna & Senpere & 21 & 65 \\
\hline Samson Hiriart & 1. zurgin & Azkaine & 27 & 90 \\
\hline Martin Habans & 2. zurgin & Ziburu & 27 & 70 \\
\hline \multicolumn{5}{|l|}{ Marinelak } \\
\hline Joannis Siogaray & marinela & Urruña & 25 & 65 \\
\hline Martin Detchegoyen & marinela & Urruña & 30 & 65 \\
\hline Joannis Gueldy & marinela & Urruña & 22 & 65 \\
\hline Saubat Darrans & marinela & Urruña & 23 & 65 \\
\hline Michel Larretche & marinela & Ziburu & 17 & 60 \\
\hline Pierre Chaumont & marinela & Donibane Lohizune & 19 & 65 \\
\hline Bertrand Guicheneguy & marinela & Senpere & 24 & 65 \\
\hline Michel Eldox & marinela & Quebec & 24 & 65 \\
\hline \multicolumn{5}{|l|}{$\underline{\text { Hasiberriak }}$} \\
\hline André Balay & marinel hasiberria & Louisbourg & 17 & 35 \\
\hline Martin Lahasson & marinel hasiberria & Senpere & 20 & 35 \\
\hline Joannis Latxalde & marinel hasiberria & Itsasu & 20 & 35 \\
\hline Joannis Behola & marinel hasiberria & Senpere & 20 & 40 \\
\hline St. Jean Detchebehere & marinel hasiberria & Ortzaize & 20 & 35 \\
\hline Joannis Bedaton & marinel hasiberria & Senpere & 20 & 50 \\
\hline Joannis Darrichury & marinel hasiberria & Donamartiri & 19 & 35 \\
\hline Martin Croux & marinel hasiberria & Senpere & 18 & 40 \\
\hline Jean Campy & marinel hasiberria & Louisbourg & 21 & 35 \\
\hline \multicolumn{5}{|l|}{ Ontzi mutilak } \\
\hline Jean Hiriart & ontzi mutila & Urruña & 16 & 35 \\
\hline Jacobe Lafargue & ontzi mutila & Ziburu & 15 & 30 \\
\hline Joannis Detchebetcho & ontzi mutila & Urruña & 18 & 35 \\
\hline \multicolumn{5}{|l|}{ Borondatezkoa } \\
\hline Jean Dotsanur & boluntarioa & Gabadi & 30 & 45 \\
\hline \multicolumn{5}{|l|}{ Erroldatuak } \\
\hline Martin Salaberry & zapatagilea & Uztaritze & 35 & - \\
\hline Pierre Dandoy & zapatagilea & Martxueta & 45 & - \\
\hline \multicolumn{5}{|c|}{$\begin{array}{l}\text { Iturria: "Rolle de l'equipage du bateau Le Dauphin de Louisbourg", The National Archives, High } \\
\text { Court of Admiralty 32/180 (1). }\end{array}$} \\
\hline * Bearnoko udalerria. & & & & \\
\hline
\end{tabular}


Borrokarako ez ezik, kortsu-ontziek marinel asko behar izaten zituzten beste ontziren bat harrapatuz gero, harrapakina portura eramateko gutxienez bigarren tripulazio bat osatzeko adina marinel behar zirelako. Le Dauphin-eko gizon gehienak euskaldunak ziren: 25 Lapurdikoak, hiru Nafarroa Beherekoak, bat Bearnokoa, eta bost Frantzia Berrikoak. Noski, gerra garaian tripulazio osoa herrialde edo monarkia berekoa izatea gauza arrunta zen. Baina azpimarratu behar da bake garaian ere ezaugarri hori nahikoa hedatua egon zela XVIII. mendeko Atlantikoan, eta eskifaikide gehienak, batik bat tonaje txiki edo ertaineko ontzietakoak, herrialde edo monarkia berekoak beharrean eskualde edo portu inguru berekoak izaten zirela. Bizkaia eta Gipuzkoan hala izan zela erakusten dut beste lan batean. ${ }^{6}$ Nantesen ere gauza bera gertatzen zen. ${ }^{7}$ Azken urteotan egin diren ikerketek eskifaikideen jatorri komuna batez ere Europa eta Atlantikoan zela arrunta erakutsi dute, baina ez horrenbeste Asia eta Indiako ozeanoan. ${ }^{8}$

Gainera euskaldunen kasuan, marinel asko elebakarrak zirenez, erabat gomendagarria izaten zen marinel guztiak, edo behintzat gehienak, euskaldunak izatea, bestela nabigazioak eskatzen zuen talde koordinazio eraginkorra gauzatzea oso zaila bihurtzen baitzen. Era berean kapitaina eta ontziko ofizialen artean euskaldun elebidunak egoten ziren, Le Dauphin-en bezala.

Eskifaikideen adinei dagokienez nabarmena da Le Dauphin-eko gehienak gizon gazteak zirela, 2. TAuLan ikus daitekeen moduan. Tripulazioaren batez besteko adina 22,8 urtekoa zen. Testu honen hirugarren atalean izango dugu gaztetasun horren inguruan gehiago esateko aukera.

6. Lamikiz, Xabier, 2008, "Basque ship captains as mariners and traders in the eighteenth century", International Journal of Maritime History 20:2, 81-109.

7. BOUYER, Murielle, 2000, "Laire de recrutement des gens de mer, par le commerce nantais au XVIIle siècle", in G. Saupin (koord.), Le Pouvoir urbain dans l'Europe Atlantique du XVIe au XVIIIe siècle, Ouest Éditions, Nantes. 165-178.

8. van Rossum, Matthias, van Voss, Lex H., von Lottum, Jelle \& Lucassen, Jan, 2010, "National and international labour markets for sailors in European, Atlantic and Asian waters, 1600-1850", in M. Fusaro \& A. Polónia (arg.), Maritime History as Global History, International Maritime Economic History Association, St.John's, Newfoundland. 47-72. 


\begin{tabular}{|c|c|}
\hline \multicolumn{2}{|c|}{ 2. TAULA. Le Dauphin-eko tripulazioa adin taldeka } \\
\hline Adin taldeak & Eskifaikideak \\
\hline$>20$ & 8 \\
\hline $20-24$ & 14 \\
\hline $25-29$ & 6 \\
\hline $30-34$ & 2 \\
\hline $35-39$ & 2 \\
\hline $40-44$ & 0 \\
\hline $45-49$ & 2 \\
\hline Guztira & 34 \\
\hline Iturria: "Rolle de l'equipage du bateau Le Dauphin de Louisbourg", The National Archives, High \\
Court of Admiralty 32/180 (1).
\end{tabular}

Marinel ugari eramateaz gain, Le Dauphin-ek borrokarako sei kanoi, hogei fusil eta hogei ezpata zeramatzan. Ez zen, beraz, harrapakin handiak erasotzeko edota etsai indartsu bati aurre egiteko moduko kortsu-ontzia. Agerian geratu zen hori 1757ko apirilaren 9an, itsasoan lauzpabost egun bakarrikzeramatzala Rochester, Somerset eta Devonshire gerra-ontzi ingelesekin topo egin zuenean. Hain zuzen ere Rochester-eko tripulazioak hartu zuen Le Dauphin-eko gizonak atxilotzeko ardura. Bi aste beranduago Lermet kapitainak berak atxilopean adieraziko zuenez, etsaiekin topo egin bezain laster haiek askoz kanoi gehiago zituztela konturatu eta zuzenean errenditzea erabaki zuen. Hala, Le Dauphin eta bere kargamentu eta tripulazio osoak Ingalaterra hegoaldera eraman zituzten, Portsmoutheko portura.

Britainiarrek gerra garaian harrapatzen zituzten itsasontziekin zer egin erabakitzea Almirantegoko Auzitegi Gorenari (High Court of Admiralty) zegokion. Harrapakina etsaiarena eta gerra hasi ostean harrapatua zela frogatzen bazen, orduan itsasontzia eta bere kargamentua subasta bidez saltzen ziren, irabaziak harrapatzailearen eta erregearen artean banatzen zirelarik. Horregatik harrapaketan parte hartutakoek, bai harrapatzaileak nola harrapakinak, lekukotasuna eman behar izaten zuten auzitegian. Le Dauphin-en kasuan galdekatuak Martin Lermet kapitaina, Dominique Leblanc bigarren kapitaina eta Pierre Derratsou tenientea izan ziren. Noski, lekukoen deklarazioez gain, Almirantegoko epaileak harrapakinari bahitutako paper eta agiri guztiak aztertzen zituen. Le Dauphin-en epaiketan egun bi kutxatan gordeta dauden agiriak aurkeztu ziren, besteak beste ontzian harrapatutako hainbat kontratu, ordainagiri, zerrenda, baimen eta korrespondentzia. ${ }^{9}$ Hain zuzen ere Le Dauphin-ek 170 gutunazal inguruk osatzen zuten posta zeraman Île Royalera, batik bat Louisbourgeko bizilagunei zuzendutakoa. Frantsesez idatzitako eskutitzak ez ezik, gutun-azalon barruan gorago aipatu euskarazko 50 eskutitzak zeuden.

9. Isasontziaren epaiketaren paperak, kortsu agiria, kontuak, kontratuak eta bestelakoak TNA, HCA 32/180 (1) kutxan daude. Aldiz, korrespondentzia osoa TNA, HCA 30/264 kutxan dago. 
Ontziaren jabeari buruz galdetu ziotenean, Lermet kapitainak erantzun zuen haren izena Monsieur Jean Laborde zela, Louisbourgeko bizilaguna. Zer dakigu Laborde horri buruz? Lapurtarra zen, Bidarten jaioa 1710ean. 1730ean bidaiatu zuen lehen aldiz Île Royalera, erregearen biltegizainaren idazkari izateko, baina berehala erakutsi zuen merkataritzan eta kortsuan inbertitzeko trebezia ere bazeukala. Austriako Ondoregotza Gerran (1740-1748) Jean Marguerie merkatariarekin elkartu zen bi kortsu-ontzitan inbertitzeko. Hala ere, 1745 eko udan britainiarrek Louisbourg harrapatu zutenean, Laborde Frantziara bueltatu behar izan zen. Hurrengo hiru urteak Rocheforten pasa zituen Île Royali zegozkion altxorzainaren kontuliburuak antolatzen. 1748an, gerra bukatu zenean, Laborde Louisbourgera itzuli zen bere emazte eta seme-alabekin. Han biziko zen familia osoa harik eta 1758an ingelesek bigarrenez gotorlekua harrapatu zuten arte. Merkatari eta ontzijabe izateaz gain, Labordek hainbat kargu bete zituen Île Royalen, besteak beste, errege-notario, Frantziaren kolonietako altxorzain orokorraren agente, eta Louisbourgeko Errege-Kontseilu Gorenaren herri-salatari. Pariseko ministeriotik jasotzen zuen diruarekin Louisbourgen zeuden soldadu, marinel, ofizial eta hornitzaileei ordaintzen zien. Hala ere badirudi Labordek (beste askok bezala) erregearen dirua bere inbertsio pribatuak finantzatzeko erabiltzen zuela. Hala, Zazpi Urteko Gerraren hasieran, irabazi galantak egiteko aukera ikusi eta, helburu hori lortu asmoz, Frantziako zenbait merkatari ospetsuren laguntzaz baliatu zen. Bordelen Dominique Cabarrus zen haren kontaktu nagusia, Bresten Yves-Augustin Bersolles, eta Baionan Jean Lanne, Le Dauphin-en pleitatzailea. Louisbourgeko gudarostea hornitzeaz gain, Labordek bost itsasontzi prestatu zituen ingelesen aurka kortsuan ari zitezen. Haietako bat zen Le Dauphin. ${ }^{10}$

Baionatik Louisbourgerako bidaia hura esplikatzen duten arrazoiak ikusi ditugu, baina hainbat galdera daude oraindik airean. Zer garrantzi zeukan Louisbourgek Ipar Euskal Herriko biztanleentzat? Galdera horri erantzutea funtsezkoa da euskarazko 50 eskutitzen presentziaren zergatia ulertzeko.

\section{Louisbourg eta euskaldunak}

Louisbourg Île Royale uhartean (egungo Cape Breton) zegoen kokatua, Kanadako Eskozia Berria probintziako ipar-ekialdeko muturrean. 1. Mapan ikus daitekeen bezala, Espainiako Ondorengotza Gerraren (1701-1713) bukaeran, Utrechteko Itunaren ondorioz, Frantziak ordu arte Ipar Amerikan izandako hainbat kolonia ingelesen esku utzi behar izan zituen, besteak beste bete-betean ekonomia atlantiarrean integratuta zeuden Akadia eta Ternua. Galera horren ondorioz, Ipar Amerikan geratzen zitzaizkion lurrek Ozeano Atlantikora irteera izaten jarrai zezaten, Frantziako erregeak Louisbourgen gotorleku handi bat eraikitzea erabaki zuen, Ipar Amerikako handiena eta garestiena izango zena. Eraikuntza lanak 1720an hasi eta 1740an bukatu zituzten. 40 hektareako lur azalera inguratzen zuen lau kilometroko luzeeradun

10. Bosher, John F., 2003, "Laborde, Jean", in Dictionary of Canadian Biography Online, 4. lib., University of Toronto / Université Laval. Le Dauphin-ez gain, ingelesek Laborden beste bi itsasontzi kortsario harrapatu zituzten gerran zehar: La Victoire (100 tonakoa) eta Le Charmant. Halaber, 1758an jabetza ugari galdu zituen ingelesek Louisbourg okupatu zutenean. 
harresia eraiki zuten. Eta teorian 148 kanoirentzako zuloak egin bazituzten ere, badirudi praktikan 100 kanoi baino gutxiago jarri zituztela. Gotorlekuaren eraikuntzan Frantziako koroak 30 milioi libera gastatu zituen. ${ }^{11}$ Historialari baten esanetan, hura izango zen Kanada frantsesarentzat "mundu atlantiarrerako leihoa". ${ }^{2}$

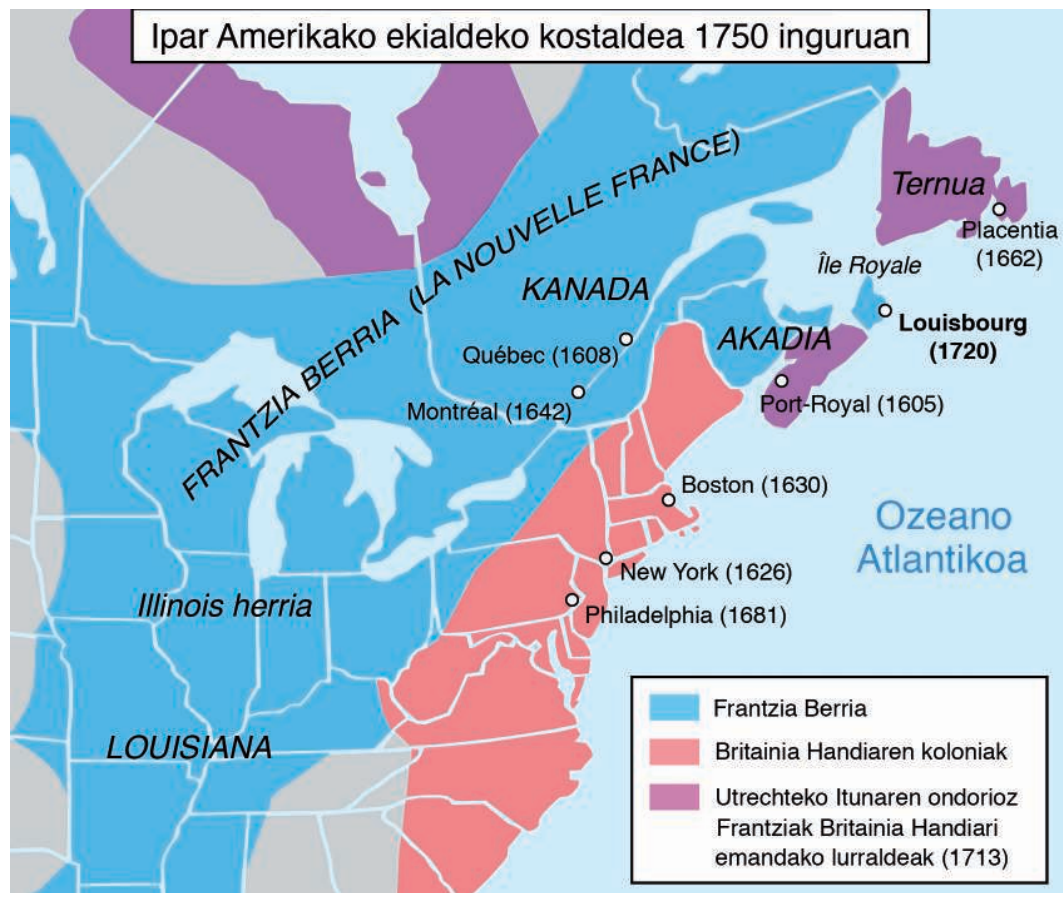

1. MAPA. Ipar Amerikako ekialdeko kostaldea 1750 inguruan. Bertsio hau ondoko iturriaren egokitzapena da: <http://en.wikipedia.org/wiki/File:Nouvelle-France_map-en.svg>

Frantzia mendebaldeko kostaldetik, Arroxela edo Baiona bezalako portuetatik, 4.100 kilometroko itsasbidea osatu beharra zegoen Louisbourgera iristeko. Harakoan lautik zortzi astera bitartean behar ziren; bueltatzeko, aldiz, hiruzpalau aste besterik ez, itsaslaster egokiagoei esker. Gero, Louisbourgetik Kanadara bidea jarraitu nahi zuten itsasontziek, beste 900 kilometro burutu behar izaten zituzten San Laurendi golkoa zeharkatu eta Quebecera iristeko.

11. Wall, Robert E., 1964, "Louisbourg, 1745", New England Quarterly 37:1, 64-66.

12. Banks, Kenneth J., 2002, Chasing empire across the sea: Communications and the state in the French Atlantic, 1713-1763, McGill Queen's University Press, Montreal, 76. 
Hala ere, Louisbourgerako itsasbidea ez zen urte guztian zehar irekita egoten. Izotz zati eta izozmendien garaian, otsaila eta martxoa bitartean, île Royale isolatuta gelditzen zen. Baina oro har neguan inguru hartan nabigatzea oso deserosoa eta zaila suertatzen zenez, Louisbourgeko itsas trafiko gehiena maiatza eta azaroa bitartean burutzen zen. Beraz ez da kasualitatea Le Dauphin Baionatik apirila hasieran itsasoratu izana. Bidaia osatu izan balu, Louisbourgera maiatza erdialdean iritsiko zatekeen.

Louisbourgera hurbiltzen ziren itsasontzien eta tonajeen berri ematen duten agiri gutxi kontserbatu diren arren, posible da, halere, urte konkretu batzuetako datuek esaten dutenetik ondorio partzial baina esanguratsu batzuk ateratzea. Louisbourgeko kaira iristen ziren ontziek bost jatorri nagusi zituzten: Kanada, Akadia, Antilla frantsesak (Martinika, Guadalupe, SaintDomingue eta Grenada), Ingalaterra Berria (Ipar Amerika ekialdeko kolonia britainiarrak) eta, batez ere, Frantzia. Arrantzaz gain Île Royalek beste produkzio-jarduera gutxi zituenez, bertako populazioari ezinbestekoa zitzaion janaria, arropa, ardoa eta beste hainbat kontsumogai inportatzea. Kontsumogai estimatuenak Frantziatik zetozen, eta Frantzia bera zen Île Royale inguruan harrapatutako arrantzaren merkatu nagusia. 1. GRAFIKOAk harreman estu horren berri ematen du. Bertan 1719-1752 epealdiko urte jakin batzutan inportatutako tonak azaltzen dira soilik, eta beraz datuon adierazgarritasuna erresalbuz hartu beharra dago. Hala ere, erakusten duten bilakaerak zentzua dauka: gotorlekua eraikitzen hasi bezain pronto inportazioen tonajea hirukoiztu egin zen, 2.500 tona ingurutik 7.000tik gora izatera pasatuz; ondorengo bi hamarkadetan inportazioak nahikoa egonkor mantendu ziren; eta, azkenik, hurrengo inflexio puntua 1750 eko hamarkadaren hasieran iritsi zen, urteroko inportazioak 14.000 tona izatera iritsi baitziren. Azken fase horrekin bat letorke batik bat Louisbourgek 1752rako bizi izan zuen populazio hazkunde nabarmena, 3. TAULAn ikus daitekeen moduan.

Baina populazioari buruz hitz egin aurretik, komeni da 1. GrafIKOAk erakusten duena astiroago aztertzea. Louisbourgeko gotorlekua eraikitzea erabaki zuenetik, gobernu frantsesak argi zeukan Île Royalek harreman ekonomiko estua eho zezakeela Kanada eta Antilla frantsesekin. Kanadatik garia, barazkiak, abereak eta egurra inporta zitzakeen Île Royalek, eta gero horren guztiaren zati bat Antilletara berresportatu. Antilletatik, ordea, beste kontsumogai batzuk ekar zitezkeen, batik bat azukrea eta kafea, baina baita tropikoko beste produktu batzuk ere. Eta, nola ez, gero Antilletako kontsumogaien zati bat Kanadara berresportatzeko aukera zegoen. Hala ere egitasmo horrek ez zuen erabat funtzionatu. Antillekin egindako merkataritza probetxuzkoa suertatu zen, batez ere Antillak île Royaleko bakailao gazituarentzako merkatu garrantzitsu bihurtu zirelako. Aldiz, Kanadako itsasbideak ez zuen interes handirik piztu. Egia esan, eraikuntzarako materialen hornitzaile nagusia ez zen Kanada izan, Ingalaterra Berria baizik. Boston eta beste portu britainiarretako merkatariek zura, abere eta burnizko tresna ugari bidali eta trukean Antilletako azukre eta ron karga handiak erosten zituzten Louisbourgen. ${ }^{13}$

13. Moore, Christopher, 1977, Merchant trade in Louisbourg, Île Royale (master tesi argitaratu gabea), University of Ottawa, 13-20. 


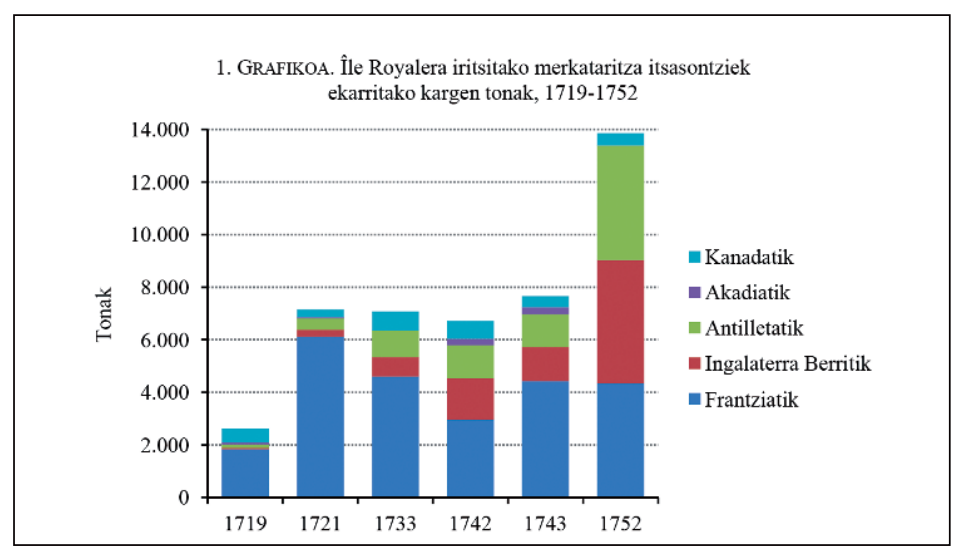

Iturria: MooRe, Christopher, 1977, "Merchant trade in Louisbourg, Île Royale" (master tesi argitaratu gabea), University of Ottawa, 20.

2. GRAFIKOAn gorago aipatu Frantziaren garrantziaz esandakoa ez da hain argi ikusten, zeren oraingoan Île Royalera kanpotik iritsitako itsasontzien kopuruak azaltzen baitira eta ez tonajeak. Baina horrek azalpen erraza dauka: Atlantikoa zeharkatzen zuten itsasontziak, hots, Frantziatik zetozenak, oro har tonaje handiagoko ontziak izaten ziren. Aurreko grafikoan bezala, hemen ere azpimarratu beharrekoa 1752ko datua da, urte horretan kanpotik etorritako 213 merkataritza itsasontzik hartu baitzuten portua Île Royalen, aurreko urteetako edozein kopururen ia doblea. Horiez gain, epealdi berean, uhartekoak bertakoak ziren beste 300 arrantza-txalupa eta goleta zeuden. ${ }^{14}$

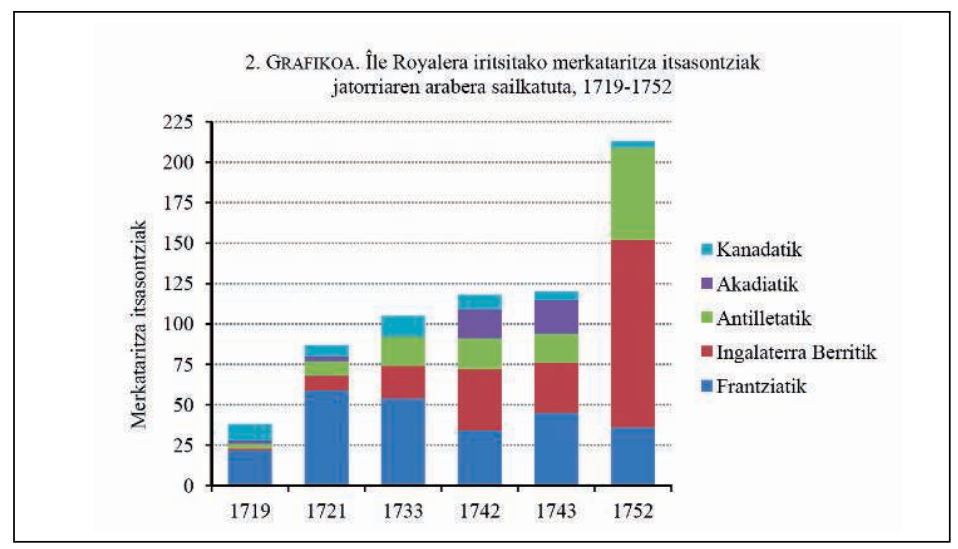

Iturria: 1. GRAFIKOARena.

14. BANKS, Chasing empire across the sea, 71 eta 75-76. 
Neurri handi batean Île Royale esatea Louisbourg esatea da, batez ere distantzia luzeko merkataritzari dagokionean. Egia esan, uhartearen inportazioek gora egin zuten Louisbourgeko populazioa hazi zen hein berean. Gainera, 3. TAULAn ikus daitekeen moduan, uharteko populazioaren ehuneko geroz eta handiagoa Louisbourgen kokatuz joan zen. Hogeita hamar urteren buruan Louisbourgeko biztanleria laukoiztu egin zen, eta 1752rako Île Royaleko populazioaren \%70ak nahiago zuen bizilekua gotorlekuaren babesean izan.

3. TAULA. Île Royale eta Louisbourgeko populazio osoa (zibila eta militarra)

\begin{tabular}{|l|c|c|c|c|c|}
\hline & 1720 & 1726 & 1734 & 1737 & 1752 \\
\hline Île Royale & 2.947 & 3.581 & 3.957 & 4.524 & 5.611 \\
\hline Louisbourg & 950 & 1.351 & 1.616 & 2.006 & 3.940 \\
\hline $\begin{array}{l}\text { Louisbourgen } \\
\text { ehunekoa }\end{array}$ & $\% 32$ & $\% 38$ & $\% 41$ & $\% 44$ & $\% 70$ \\
\hline
\end{tabular}

Iturria: Johnston, Andrew J.B., 2001, Control and order in French colonial Louisbourg, 17131758, Michigan State University Press, East Lansing, 38.

Noski, babesaz gain Louisbourgek jarduera ekonomiko nahikoa erakargarriak eskaintzen zizkien bertara hurbiltzen zirenei: bakailaoaren arrantza; bakailao gazituaren esportazioa Europara zein Ameriketara; Europako ohial, ardo, pattar, arma, bolbora, argizari, paper eta bestelakoen inportazioa; eta gotorlekuko ehundaka soldaduen beharrizanak asetzea. ${ }^{15}$ Arrantza oparoari esker, Louisbourgen (eta Île Royalen oro har) hainbat arrantzale egoten ziren urtean zehar. Batzuek bertan zeukaten etxebizitza, baina gehienak arrantza denbora aproposena aprobetxatzera beren-beregi Europatik etorriak ziren. 1752ko neguan eginiko errolda batek erakusten duenez, momentu hartan 199 arrantzale zeuden Île Royalen negua igarotzen, eta erdia inguru Lapurditik etorritakoak ziren. Horrek esan nahi du arrantzarako sasoirik hoberenean, hots, maiatzetik irailera, arrantzale euskaldunen kopurua 200-300 bitartekoa izatera irits zitekeela. ${ }^{16}$ Hala, 1752 ko errolda berean ageri denez, pêcheurs gehienak Frantziako bi eskualdetik zetozen: \%48a hego-mendebaldekoa zen (ia denak Baiona eta Donibane Lohizune aldeko parrokietakoak) eta \%37a Saint-Malo aldeko portuetakoa.

Nola ez, Louisbourgen bazeuden bertan bizi ziren artisau eta merkatari euskaldunak ere, eta haien emazte eta familiak. Antza denez, guztira biztanleriaren \%15a osatzen zuten. ${ }^{17}$

15. Turgeon, Laurier, 1982, "Pêches basques en Atlantique Nord (XVIIe - XVIIIe siècles): étude d'économie maritime" (doktore tesi argitaratu gabea), Université de Bordeaux III); GreER, Allan, 1977, The people of New France, University of Toronto Press, Toronto, 97-101.

16. Johnston, Andrew J.B., 1966, Life and religion at Louisbourg, 1713-1758, McGill Queen's University Press, Montreal, 7.

17. BANKS, Chasing empire across the sea, 43-46. 
Horietako batzuk, merkatari izateaz gain, arrantza konpainia baten jabeak ziren. Adibide nabarmenena Michel Daccarrette (c.1690-1745) hendaiarrarena litzateke: 1704 baino lehen Ternuako Placentian kokatu zen bere bi anaiekin arrantzan aritzeko, baina 1713an, ingelesek bertako biztanle frantsesak kanporatu zituztenean, Île Royalen kokatzea erabaki zuen, bertan ospedun ontzijabe, kortsario eta merkatari bihurtu zelarik. Negozioak burutzeko oso lagungarriak izan zitzaizkion Baiona eta Donibane Lohizuneko zenbait merkatarirekin mantendu zituen harreman estuak. Daccarrette 1745ean hil zen, ingelesek lehen aldiz Louisbourg setiatu eta harrapatu zutenean, Austriako Ondorengotza Gerraren garaian. ${ }^{18}$ Haren semea, Michel, 1730ean Louisbourgen bertan jaioa, Le Dauphin-en frantsesezko gutuneriaren hartzaileetako bat zen. Aita bezala, bera ere merkataria zen. ${ }^{19}$

Île Royalen arrantzan zein beste jarduera batean aritzen ziren euskaldun askok han lortutako irabazien parte bat Euskal Herrian zituzten senideei bidaltzen zieten. Txanponak postaz bidaltzea arriskutsuegia zenez, batez ere gerra garaian, dirua transferitzeko kanbio-letrak erabiltzen zituzten (frantsesez lettre de change, gaztelaniaz letra de cambio). Funtsean kanbioletrak txeke baten modura funtzionatzen zuen: Louisbourgetik Euskal Herrira dirua bidaltzeko lehenik hango merkatari bati letra çhanja (hala izendatzen dute eskutitzetan) bat erosi behar zitzaion, zeina merkatariak Baiona edo Donibane Lohizunen zeukan kontaktu baten kontra idazten baitzuen (hau da, kontaktuari eskatzen zion Louisbourgen jasotako diru kopurua kanbio-letra etxera eramaten zion pertsonari ordaintzea); ondoren igorleak kanbio-letra postaz bidaltzen zion dirua jaso behar zuen senideari; eta, kanbio-letra jaso bezain pronto, senidea Louisbourgeko merkatariaren kontaktuarengana joaten zen dirua kobratzera. Kasu horretan ez zegoen txanpon truke edo kanbiorik, zeren Louisbourgen eta Frantzian liberak (livres tournois) erabiltzen zituzten. Kanbio-letren zerbitzua eskaintzen zutenak normalean merkatariak izaten ziren, nola ez, komisio baten truke. Adibidez Joannes d'Etcheverry izeneko marinel batek bere aitari diru kantitate bat bidali zion kanbio-letra bidez. Aitak jaso zuenean zera erantzun zion:

Errezibitu dugu zure letra xanja, 919 liberako bat zeina plazer handia hartu baitut arribatu denean, hainbertze arriskuren ondoan..$^{20}$

Noski, kanbio-letra jasotzeak ez zuen esan nahi dirua poltsikoratuta zegoenik. Kobratzera joan beharra zegoen. Beste eskutitz batzuk bigarren pauso horren berri ematen dute. Catalin Lalannek, adibidez, zera idatzi zion bere senarrari:

18. Le Goff, Timothy J.A., 2003, "Daccarrette, Michel", in Dictionary of Canadian Biography Online, 3. lib., University of Toronto / Université Laval. 1745ean Louisbourgeko setioa burutu zutenak Ipar Amerikako kolono britainiarrak izan ziren. Guztira 4.000 gizon, 27 itsasontzi eta 788 kanoi erabili zituzten britainiarrek Louisbourg sei asteko erasoaren ondoren okupatzeko: Wall, "Louisbourg, 1745", 73-74.

19. Etiene Cabarrusek Michel Dacarretteri, Baiona, 1757/3/28, TNA, HCA 30/264, 100. gutunazala. Gutun-azalaren barruan frantsesez idatzitako eskutitzak eta kontuak daude.

20. Jatorrizko testuan: "Errecibitu dugu / çure lettra chanja 919" liberaco bat ceina placer han / dia hartu baitut arribatu denean hainberce arriscuren / ondoan". Joannes d'Echeverryk Joannes d'Etcheverryri, Sara, 12/3/1757, TNA, HCA 30/264, 24. gutun-azala (edizio honetako 19. gutuna). 
Letra hau eskiribatzen darotzut zuri erraiteko errezebitu nuela zure letra 120 liberako letra sanjarekin, zeintaz pagatua izan bainaiz. ${ }^{21}$

Ez dakigu Le Dauphin-eko zenbat eskifaikide ziren lehenagotik Louisbourgen egonak. Ziurrenik ontzi mutil eta marinel hasiberri gehienentzako hura izan zen Île Royalera hurbiltzeko egindako lehen saiakera. Aldiz, litekeena da beste eskifaikide gehienek, 1757an britainiarren esku erori aurretik, Atlantikoa behin baino gehiagotan zeharkatu izana. Bake garaian marinel horiek merkataritza itsasontzietan ez ezik, île Royaleko arrantza konpainietan aurki zezaketen enplegua. Konpainion bilakaerari buruz ditugun datuek zera diote: jabe edo nagusi kopuruaren arabera gure epealdiaren bukaera aldera konpainia gehiago zegoela hasieran baino, eta berdin gertatzen zela langile kopuruarekin ere. Hala ere, 4. TAULAn ikus daitekeen bezala, konpainien tamaina eta kapital inbertitua ez zen gehiegi aldatu. Koloniaren lehen zein azken urteetan batez bestez arrantza konpainia batek hogei langile baino gutxiago izaten zituen eta bi edo hiru txalupa.

\begin{tabular}{|l|c|c|c|c|c|c|}
\hline \multicolumn{7}{|c|}{ 4. TAULA. Île Royaleko biztanleen arrantza konpainiak, 1724-1753 } \\
\hline & Jabeak & Langileak & $\begin{array}{c}\text { Langileak } \\
\text { jabe } \\
\text { bakoitzeko }\end{array}$ & $\begin{array}{c}\text { Txalupak } \\
\text { (shallop) }\end{array}$ & $\begin{array}{c}\text { Txalupak } \\
\text { jabe } \\
\text { bakoitzeko }\end{array}$ & $\begin{array}{c}\text { Goletak } \\
\text { (schooner) }\end{array}$ \\
\hline 1724 & 82 & 1.056 & 12,8 & 168 & 2,0 & 36 \\
\hline 1726 & 86 & 1.551 & 18,0 & 278 & 3,2 & 21 \\
\hline 1734 & 106 & 1.625 & 15,3 & 263 & 2,5 & 28 \\
\hline 1753 & 119 & --- & --- & 225 & 1,9 & 62 \\
\hline $\begin{array}{l}\text { Iturria: Moore, Christopher, 1977, "Merchant trade in Louisbourg", île Royale (master tesi } \\
\text { argitaratu gabea), University of Ottawa, 106. }\end{array}$
\end{tabular}

Ipar Euskal Herriaz gain, zer beste jatorrikoak ziren Île Royaleko biztanleak? 1713 ondoren sortutako kolonia izanik, Louisbourgeko biztanle gehienak Europan jaioak ziren. Frantzia zen sorterri nagusia baina ez bakarra. Gainera, gotorlekuko hizkuntza nagusia frantsesa zen arren, bertako kaleetan bazegoen beste mintzaira batzuk entzuteko aukera ere. Horien artean euskara zen printzipala. Frantsesaz eta euskaraz aparte, bretoiera, alemana, gaztelania, ingelera eta bertako amerindiarren mikmakera erabiltzen ziren. Halaber, gotorlekuko soldaduen artean Frantziaren soldatapean zeuden hainbat herrialdetako europarrak zeudenez, litekeena da haietako batzuk italieraz, portugesez edo nederlanderaz mintzatu izana. Baina, esan bezala,

21. Jatorrizko testuan: "Letra hau esquiribatcen darotçut / çuri erraiteco errecebitu nuela / çure lettra 120 liberaco / letra sanjarequin cenitaz / pagatua içan bainaiz". Catalin Lalannek Esteben Gourdori, Sara, 1757/2/14, TNA, HCA 30/264, 120. gutun-azala (edizio honetako 5. gutuna). 
frantsesaren ondoren, hizkuntza erabiliena ehundaka arrantzalek eta zenbait merkatari eta artisauk zerabilten euskara zen.

Erlijioari dagokionez Louisbourgeko biztanle gehienak katolikoak ziren, salbuespen bakarrak zenbait soldadu aleman eta suitzar zirelarik. Euskaldunek apaiz euskaldunak ekartzen zituzten Lapurditik meza emateko eta aitorpenak egiteko. Hau oso garrantzitsua zen euskaldunentzat, euretako asko euskaraz soilik mintzatzeko gai baitziren (ikus, liburu honetan, "Euskara Île Royalen, dokumentuen argitan",77-81). Horrez gain, epaiketaren batean parte hartzen zuen euskaldunak (eta bretoiak ere) interprete baten laguntza eska zezakeen frantsesa itzul ziezaion. ${ }^{22}$

Gehienbat bake garaiaz aritu gara orain arte, baina azpimarratu behar da Louisbourgek leku garrantzitsua okupatu zuela bai Austriako Ondoregotza Gerran (1740-1748) eta bai Zazpi Urteko Gerran (1756-1763), bertan jasotzen baitzuten babesa Ipar Atlantikoan aritzen ziren hainbat kortsu-ontzi frantsesek. Horregatik, bake garaiko jarduera ekonomikoak ez ezik behar-beharrezkoa da gerra garaikoak ere aipatzea. Izan ere, Le Dauphin-eko itsasgizonek gerra garaiko etekin handiagoek erakarrita hartu zuten Atlantikoa zeharkatzeko ardura.

\section{Kortsuaren erakarmena eta arriskua}

Gerra hasi bezain laster, bake garaian arrantzan edo merkataritzan aritzen ziren marinelek itsasontzi kortsarioetan aurkitzen zuten enplegua. Arriskua nabarmena zen, baina irabaziak ere arriskuaren parekoak izan zitezkeen. Beraz, Le Dauphin-ena ez zen inolaz ere kasu bakana. Zazpi Urteko Gerra garaiko kortsario frantses gehienak Baionan eta Dunkerquen izan ziren pleitatuak. Hain zuzen ere Baionatik 300 baino gehiago atera ziren gerran zehar. ${ }^{23}$ Jakina, euskarazko eskutitzetan kortsuaren garrantzia azpimarratzen duten aipamen ugari daude. Adibidez Pierre Detchegaray zeritzan Azkaineko bizilagunak bere koinatari zera idatzi zion:

Donibanen badire hemezortzi korsuzale untzi istileroan, eta korsurat goanak gehiago; ezta hemen bertze negoziorik korsua eta korsua baizik. ${ }^{24}$

Betry Daguerre Sarako bizilaguna kortsu-ontzi batean abiatzeko zorian zegoen. Hori bera kontatu zion Paspébiacen (Akadia kostaldean) arrantzan zebilen bere anaia Martinchori:

22. Johnston, Andrew J.B., 2001, Control and order in French colonial Louisbourg, 1713-1758, Michigan State University Press, East Lansing, 48-49.

23. Dull, Jonathan R., 2005, The French navy and the Seven Years' War, University of Nebraska Press, Lincoln, 61. Britainia Handiak ere gogoz ekin zion kortsuari. Zazpi Urteko Gerran 1.679 itsasontzi baimendu zituen kortsuan aritzeko. Gehienak Londres, Bristol eta Liverpooleko merkatarienak ziren: STARKEY, British privateering, 165.

24. Pierre Detchegarayk Catherine Gelosi, Azkaine, 1757/3/22, TNA, HCA 30/264, 9. gutun-azala (edizio honetako 36 gutuna). Pasartea honela azaltzen da eskutitzean: "donibanen badire hemesorsi Corsucale untçy / istileroan Eta Corsurat goanac guehiago Esta hemen / Berse negosiori Corsua Eta Corsua baisic". 
Nola ezten untzirik hurat heldu, hautako jende guzia korsurat ganki, ni ere korsurat nindoan lotinent, eta Monsieur Detçheverri ondoko hamalau pezetako korsuzale batean; Monsieur Harismendirekin partitzeko prest ginen hemendik lau ilabeteren buruko. Uste dut izaren direla 40 korsuzale kanpoan. ${ }^{25}$

Lapurdiko marinel familietako gizon gehienek aurkitzen zuten kortsu-ontzietan enplegua, Sarako Martin Bordak bere seme Andrecori idatzitako eskutitzak aditzera ematen duen moduan:

Anaia Guanes kortsuan dabila, hirugarren kanpainan guana da; eta aita bera ere bigarrenean doha kortsurat, joite handi baten beldurrean. Berrogoi untzi Donibanetik eta Baionatik badoha kortsurat. $^{26}$

Gerra hasi zen momentu beretik, 1756ko maiatzean, Britainia Handiko erregeak Frantziakoak baino gerra-ontzi gehiago zituen. Urte bat beranduago, 1757ko ekainean, errege ingelesak mota handieneko 96 gerra-ontzi zituen itsasoan (ships of the line direlakoak), errege frantsesak aldiz 42 soilik. Horrezaz gain, urte horretan zehar britainiarrek beste hamaika eraiki zituzten (baita hamahiru fragata ere). Hala ere, ontzi gehiago izatea ez zen diru edo baliabide kontua bakarrik; itsasoratuko zituzten marinel kopuru nahikoa lortzea zen beste arazo nagusia. Gainera, itsasbazterreko merkataritzan aritzen ziren ontziek —itsasbazterrekoa zen gerra garaian arrisku gutxirekin burutu zitekeen itsas-merkataritza mota bakarra- ez ezik, kortsu-ontziek ere marinel askoren beharra zeukaten, eta ondorioz erregearen gerraontziei konpetentzia egiten zieten, bai Britainia Handian eta bai Frantzian. Hala eta guztiz ere, gerran zehar britainiarren itsas armada gai izan zen 60.000 marinel mobilizatzeko; frantsesa aldiz 35.000 besterik ez. ${ }^{27}$

Zergatik zuten nahiago marinel frantsesek kortsu-ontzietan izena eman erregearen ontzietan baino? Erantzuna erraza da: Erregek soldata txikiagoak eskaintzen zituen, eta gainera haren ogasunak soldatok garaiz ordaintzeko arazo larriak izaten zituen. Ondorioz marinelek nahiago zuten Le Dauphin bezalako kortsarioetan lan egin. Arazo horri aurre egiteko 1757ko udan kortsua debekatzeko saio bat egon zen Frantzian, baina ez zuen arrakastarik izan zeren ordurako nabaria zen frantses kortsarioek kalte handia egin ziezaieketela britainiarrei. Hala

25. Jatorrizko testuan: "Nola Esten untchiriq hourat heldu hautaquo jende gucia Corsurait ganci / niere Corsurait nindoan Lotinent Eta Monsieur Detçheverri ondoquo / haumalau pecetaquo Corsusale baitean Monsieur harismendirequin parti / cequo prest guinen hemendiq Lau jlabeteren buruquo uste dut jcaren / direla 40 Corsusale Canpoan". Betry Daguerrek Martincho Daguerreri, Getaria, 1757/3/20, TNA, HCA 30/264, 70. gutun-azala (edizio honetako 33. gutuna).

26. Jatorrizko testuan: "anaya guanes Cortsuan dabila / hirugarren Campainan guanada eta aita Bera ere Bigarrenean / doha Cortsurat joite handiBaten Beldurrean Berrogoi / untçi donibanetic eta Bayonnatic badoha Corsurat". Martin Bordak Andreco Bordari, Sara, 1757/3/1, TNA, HCA 30/264, 67. gutun-azala (edizio honetako 10. gutuna).

27. Dull, The French navy, 87. 
ere, gerra hasi bezain laster agerian geratu zen Frantziak arazo handiak izango zituela gatazkan garaile ateratzeko: 1757an soilik britainiarrek 14.000 itsasgizon frantses espetxeratu zituzten, horietako erdia baino gehiago Le Dauphin bezalako kortsu-ontzietan harrapatuak.

Marinelen hileroko soldatak nabarmen hazten ziren gerra garaian. 1750eko hamarkada hasieran, hots bake garaian, arrantzan zebiltzatenen soldatak merkataritza edo gerra-ontzietako marinelen soldatak baino txikiagoak izaten ziren. Kapitain batek 110 libera irabaz zitzakeen hilero, kontramaisuak 48, zurginak 35, marinelek 20-30 bitartean, eta marinel hasiberriek 10-20 bitartean besterik ez. Normalean bi hilabeteko soldata jasotzen zuten itsasoratu aurretik, eta janari eta arropari dagokionez ematen zieten:

[...] à chacun une chopine de vin par repas, de leur fournir de bon pain et de la viande deux fois par semaine et des légumes et autres choses nécessaires comme aussi d'habits et ustencilles de pêche, de leur fournir pareillement de tafia suivant l'usage. ${ }^{28}$

5. TAULAk Le Dauphin-eko bake garaiko eta erregearen gerra-ontzietako soldatak konparatzeko aukera ematen digu. Argitu beharra dago bake garaiko soldatak, 1755ekoak alegia, Frantzia Berrirako itsasbidea egiten zuten merkataritza itsasontzietakoak izateaz gain lagin nahikoa handi batetik ateratako batez bestekoak direla. Garbi ikusten da erregeak ordaintzen zituen soldatak ez zirela ontzi pribatuetakoak bezain handiak, eta erregearen gerraontzietan maila goreneko ofizialak zirela merkataritza ontzietako kapitainek baino gehiago irabazten zuten bakarrak

\begin{tabular}{|c|c|c|c|c|c|}
\hline \multirow[t]{2}{*}{ Maila } & \multicolumn{2}{|c|}{ Le Dauphin (1757) } & \multicolumn{2}{|c|}{$\begin{array}{c}\text { Frantzia Berrirako } \\
\text { merkataritza ontzietan (1755) }\end{array}$} & \multirow{2}{*}{$\begin{array}{c}\text { Errege-itsasontzietan } \\
(1755) \\
\text { Soldata }\end{array}$} \\
\hline & Soldata & Adina & Soldata & Adina* & \\
\hline Kapitaina & $160(1)^{* *}$ & $26(1)$ & $155(32)$ & $36(43)$ & 300 \\
\hline 2. Kapitaina & $130(1)$ & $24(1)$ & $124(33)$ & $28(42)$ & $200-300$ \\
\hline Tenientea & $100(1)$ & $24(1)$ & $89(17)$ & $29(25)$ & 100 \\
\hline Entseinaria & $70(1)$ & $20(1)$ & $50(9)$ & $23(13)$ & 50 \\
\hline Kirurgialaria & $75(1)$ & $37(1)$ & $65(17)$ & $30(26)$ & $50-75$ \\
\hline Kontramaisua & $90(1)$ & $47(1)$ & $77(26)$ & $34(25)$ & $40-50$ \\
\hline Zurgin maisua & $90(1)$ & $27(1)$ & $76(26)$ & $33(35)$ & $36-40$ \\
\hline
\end{tabular}

28. Bosher, John Francis, 1975, "A fishing company of Louisbourg, Les Sables d'Olonne, and Paris: La société du Baron d'Huart, 1750-1775”, French Historical Studies, 9:2, 267-268. 


\begin{tabular}{|c|c|c|c|c|c|}
\hline 2. zurgina & $70(1)$ & $27(1)$ & $56(13)$ & $28(13)$ & $18-30$ \\
\hline $\begin{array}{l}\text { Kanoien } \\
\text { arduraduna }\end{array}$ & $65(1)$ & $21(1)$ & $60(10)$ & $31(16)$ & $40-50$ \\
\hline $\begin{array}{l}\text { Marinel } \\
\text { trebatua }\end{array}$ & $64,4(8)$ & $23(8)$ & $42(267)$ & $26(554)$ & $10-15$ \\
\hline $\begin{array}{l}\text { Marinel } \\
\text { hasiberria }\end{array}$ & $37,8(9)$ & $\begin{array}{c}19,5 \\
(9)\end{array}$ & $24(132)$ & $21(224)$ & 0 \\
\hline Ontzi mutila & $33,3(3)$ & $\begin{array}{l}16,3 \\
(3)\end{array}$ & $13(65)$ & $15(111)$ & $3-6$ \\
\hline \multicolumn{6}{|c|}{$\begin{array}{l}\text { Iturriak: "Rolle de l'equipage du bateau Le Dauphin de Louisbourg", The National Archives, } \\
\text { High Court of Admiralty 32/180 (1); Proulx, Gilles, 1984, Between France and New France: Life } \\
\text { aboard the tall sailing ships, Dundurn Press, Toronto, 86. } \\
\text { * Frantzia Berrirako merkataritza ontzietako itsasgizonen adinak berez } 1745 \text { eta } 1755 \text { eko } \\
\text { tripulazio zerrendetatik ateratako batez bestekoak dira. } \\
\text { ** Soldata eta adinaren ondoko parentesi arteko zenbakiak itsasgizonen kopurua adierazten du. } \\
\text { Lagina pertsona batek baino gehiagok osatzen duenean soldaten eta adinen balioak kasu kopuru } \\
\text { osoen batez bestekoak dira. }\end{array}$} \\
\hline
\end{tabular}

Bake garaiko soldatek oso gorabehera gutxi jasan zituzten XVII. mende erdialdetik XVIII.aren erdialdera arte. Baina gerra pizten zen bakoitzean soldatek bat-batean gora egiten zuten, batik bat marinelenek. Hala gertatu zen Zazpi Urteko Gerraren hasieran. Ralph Davis historialariaren hitzetan, Ingalaterran gatazkaren hasierak "sent wages up to extraordinary heights" ${ }^{29}$ Bake garaian marinel ingeles trebatu batek 25 shilling (16,5 libera tournois) jasotzen zituen hilero, baina 1757-1758ko neguan 70 shilling (46,5 libera) kobratzera iritsi zen; hots, \%180ko soldata igoera! ${ }^{30}$ Hala ere Davisek azpimarratzen du igoera soilik marinelen kasuan izaten zela nabarmena. Beste eskifaikideen soldatak gutxiago puzten ziren, eta kapitainarena ia ezer ez.

Ingalaterraren kasua, hau da, Frantziaren etsaiarena, 5. TAULAk erakusten digun informazioarekin alderatzen badugu, argi dago Frantzian, edo bederen Baionan, soldaten igoera ez zela hain ikusgarria izan. 1755eko soldatak Le Dauphin-ekoak baino txikiagoak dira, baina bien arteko tarteak ez dira Davisek aipatzen dituen bestekoak, ezta gutxiagorik ere. Hori bai, igoeraren benetako onuradunak marinelak eta ontzi mutilak izan ziren. Marinel trebatuen soldata igoera \%53koa izan zen, marinel hasiberriena \%57koa, eta ontzi mutilena \%156koa. Aldiz beste eskifaikideen soldatak, batez bestez, \%13 besterik ez ziren igo. Maila bakoitzean gertatu zen igoera argiago ikus daiteke 3. GRAFIKOAn. Gainera gerra garaian badirudi eskifaikideek ohikoa zena baino soldata aurrerapen handiagoak jasotzen zituztela: bake

29. Davis, The rise of the English shipping industry, 131.

30. Txanpon ingelesetik frantseserako konbertsioa egiteko honako webgunea erabili da: <http:// www.pierre-marteau.com/currency/converter/eng-fra.html> 
garaian itsasbidaia hasi aurretik hilabete bat edo biko soldata boltsikoratzea ohikoa bazen, ${ }^{31}$ gerra garaian hiru hilabeteko aurrerapena jasotzera iritsi zitezkeen, Le Dauphin-en bezala. Hala ere, kortsu-ontzietako marinelek, soldataz gain, beste diru sarrera bat ere izan zezaketen: etsaiaren ontziak harrapatzeagatik euren enplegatzaileak emango zien diru-saria. Le Dauphinen kasuan ez dakigu diru-sariaren zenbatekoa aurretik adostuta zegoen ala ez, baina argi dago marinelek, kortsu-ontzi guztietako tripulazioek bezalaxe, etsaiaren ontzi aberats eta mantso bat aurkitzearekin egiten zutela amets.

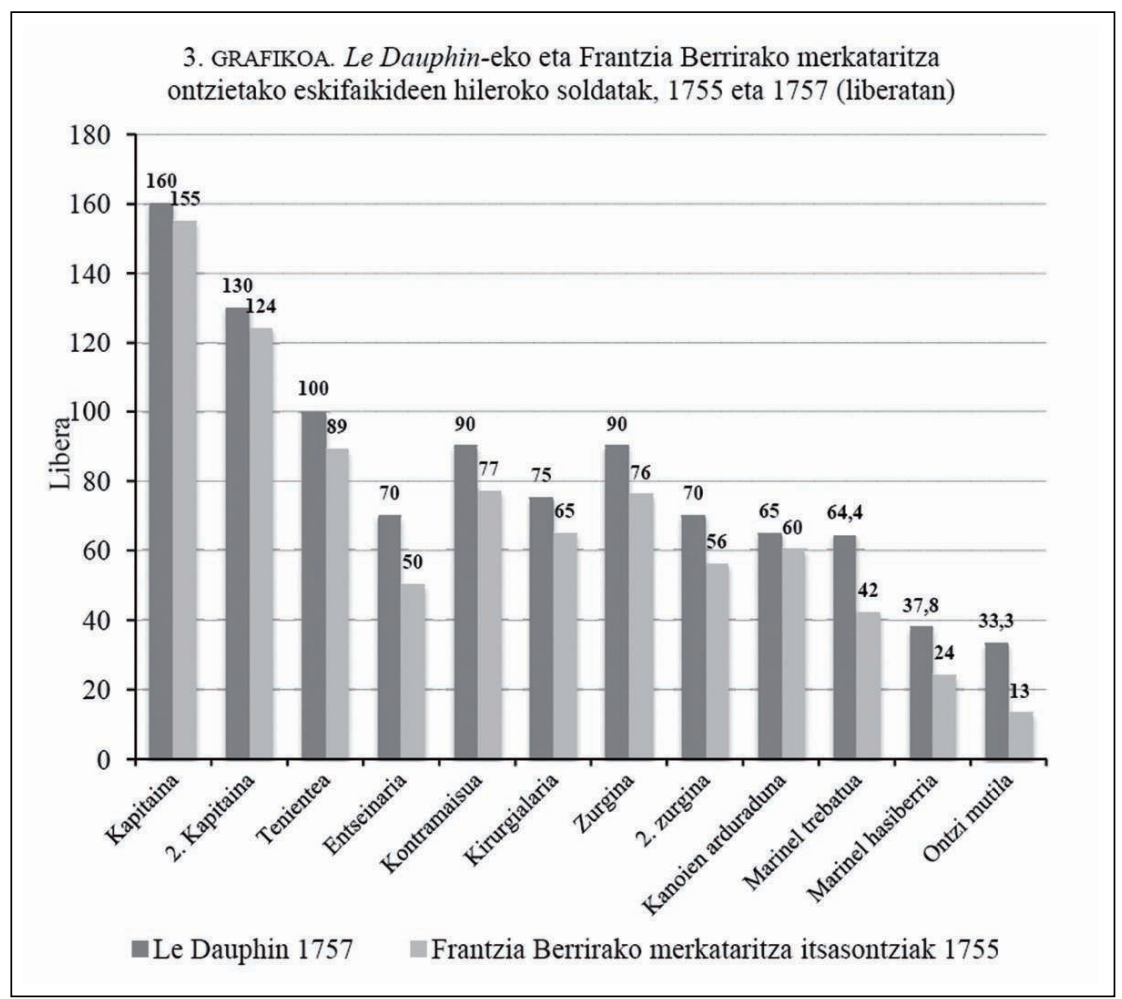

Iturriak: 5. TAULArenak

31. Proulx, Between France and New France, 85; Bosher, "A fishing company", 267. 


\section{GRAFIKOA. Le Dauphin-eko eta Frantzia Berrirako merkataritza} ontzietako eskifaikideen adinak, 1745,1755 eta 1757

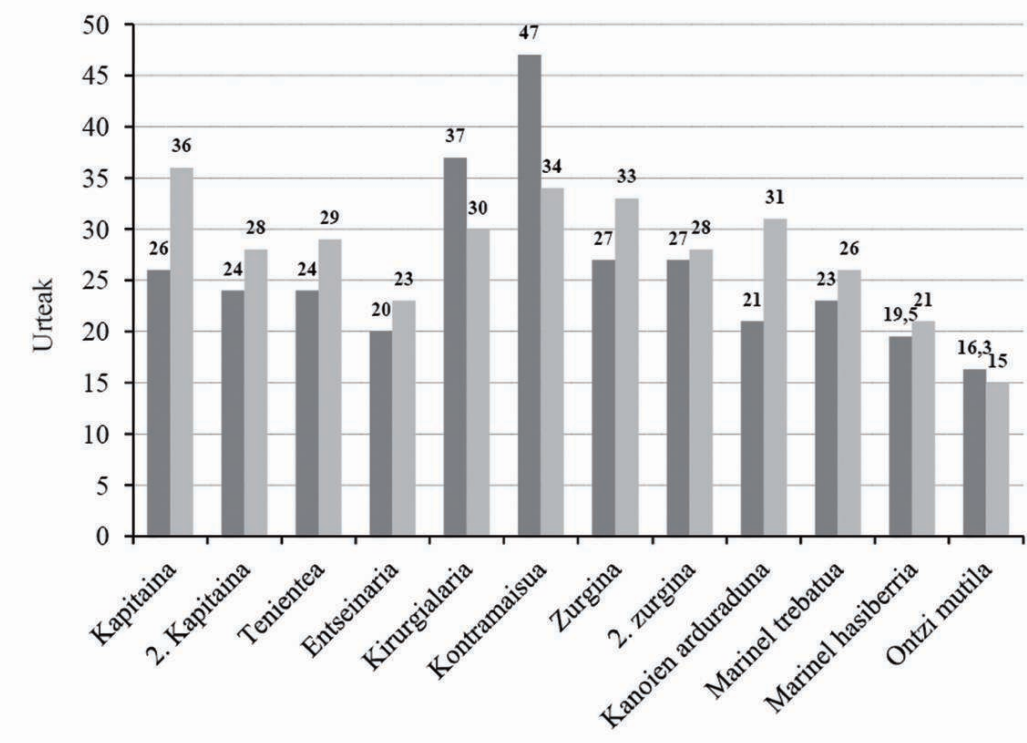

—Le Dauphin 1757 Frantzia Berrirako merkataritza itsasontziak 1745 eta 1755

Iturriak: 5. TAULArenak

Gorago aipatu dugu Le Dauphin-eko tripulazioaren batez besteko adina 22,8 urtekoa zela, eta eskifaikideen \%65ak 24 urte edo gutxiago zituela. 5. TAuLaren laguntzaz Le Dauphineko tripulazioaren adinak itsasbide bera egiten zuten tripulazioen batez besteko adinekin alderatu ditzakegu. Hain zuzen ere 1755eko adinen batez besteko haztatua 25 urte da. Beraz Le Dauphin-eko tripulazioa oro har gazte samarra zela ondoriozta daiteke. Maila bakoitzeko adinen konparaketa 4. GRAFIKOAn dago ikusgai. Agian gaztetasun horren arrazoia ordurako eskarmentu gehiagoko marinel gehienak itsasoratuta zeudela izan liteke. Beste zergati posible bat gizon gazteagoek arriskuarekiko izan ohi duten jarrera ausartagoa izan liteke.

Jasotzen zuten soldataz gain, merkataritza ontzidian lan egiten zuten itsasgizonek normalean eurek erositako merkagaiak eramaten zituzten ontzi barruan gero kolonietan saldu eta etekin bat atera ahal izateko. Hala jokatzea ohiko praktika zen bake garaian. Adibidez, 1756ko udaberri hasieran Les Sables d'Olonnetik Ipar Amerikarantz atera zen Duc d'Anjou 105 tonako ontziaren kapitainak bereak ziren 30 upel likore, 6 upel melokotoi, 12 upeltxo ozpin, 6 upel almendra, 30 urdaiazpiko, 100 gazta eta 750 kilo inguru soka zeramatzan bere kontura. Egia esan, praktika horri esker itsas armadako eskifaikideek irabazten zutena baino bi edo hiru aldiz gehiago irabaz zezaketen merkataritza ontzidian enplegua lortzen zuten itsasgizon trebatuek. ${ }^{32}$

32. Proulx, Gilles, 1984, Between France and New France: Life aboard the tall sailing ships, Dundurn Press, Toronto, 85. 
Portsmouthen galdekatu zutenean, Lermet kapitainak adierazi zuenez "neither he or any of the officers or mariners belonging to [Le Dauphin] had any part, share or interest in her or in any of her lading (except private adventures)" ${ }^{33}$ Hau da, ofizialak eta marienelak ez ziren ontziaren kargamentuaren jabeak, baina euretako batzuk bazeramatzaten zenbait merkagai ekipajearekin batera. Lermet kapitainak berak aitortu zuen "that he hath lost by the capture and detention of [Le Dauphin] his private adventure of hams, brandy and his cloathes to the value of three hundred and fifty livres". ${ }^{34}$ Hau da, Lermetek 350 liberako balioa zuten urdaiazpikoak, brandia eta arropak zeramatzan ontzian; Dominique Leblanc bigarren kapitainak aldiz 1.500 liberako balioa zuten zapata eta antxoa mordoa; eta, galdekatua izan zen hirugarren eskifaikideak, Pierre Derratsou tenienteak, guztira 50 libera balio zuten zenbait arropa. ${ }^{35}$

5. TAULAn azaltzen diren soldatekin itsasgizonek zer eros zezaketen ikusteko nahikoa da oinarrizko jaki eta produktu batzuen prezioei so egitea. Le Dauphin harrapatu zuten urte berean (urteko garaia zehaztu gabe dagoen arren), adibidez, 80 kiloko upel irin batek 27 libera balio zituen, bilgorrez beteriko upel batek 50 libera, mailu batek bi libera, eta Borgoñako ardo botila batek libera bat eta hamar sos. ${ }^{36}$ Argi izan behar dugu, hala ere, gerra garaian soldatek ez ezik inflazioak ere gora egiten zuela. Gorago aipatu eskutitzaren egileak, Pierre Detchegarayk, hori bera salatzen zuen. Baiona eta Donibane Lohizuneko marinel gehienak kortsuan ari zirela aipatu ondoren, zera zioen: "Eta bizia garastia: ogia aski arrazoin da, bainan arnoa eta gazia dira garastia" ${ }^{37}$ Francha Barrerek bere senar Pierre Hayete zapatagileari bakailaoa bidali izana eskertu ez ezik gehiago bidaltzeko eskatzen zion "ezen hemen ere gauza guziak garastia dire". ${ }^{38}$

Baina gerrak bazuen inflazioa baino alde txarrago bat. Kortsuan arituz marinelek, eta itsasgizonek oro har, soldata handiagoak jasotzen zituztela egia den arren, ez da ahaztu behar diru sarrerek gora egiten zuten heinean, nola ez, zauritua, hilda edo atxilotua suertatzeko aukerek ere gora egiten zutela, nabarmen gainera. Martin Arrundek bere semeari esan bezala, "Deusik ezin irriska dezakeguke: unzi guzijak artzen tuzte". ${ }^{39}$ Martin Durruitzek ere bere semeari antzerako berri txarrak eman nahi zizkion: "Eta Martin gazte kortsutara goan eta presan heldu dela, angelesek harturik Plemuan [Plymouthen] da". ${ }^{40}$

33. "Deposition of Martin Lermet", TNA, HCA 32/180 (1).

34. Ibid.

35. "Deposition of Dominique Leblanc" eta "Deposition of Pierre Derratsou", TNA, HCA 32/180 (1).

36. Proulx, Between France and New France, 85.

37. Pierre Detchegarayk Catherine Gelosi, Azkaine, 1757/3/22, TNA, HCA 30/264, 9. gutun-azala (edizio honetako 36a gutuna). Berez, pasartearen jatorrizko grafia honakoa da: "Eta bisia / garastia oguia asci arasoinda bainan arnoa eta gacia dira / garastia."

38. Jatorrizko testuan: "ezen hemen ere gauça guçiac Garastia dire", Francha Barrerek Pierre Hayeteri, datarik gabea, TNA, HCA 30/264, 117. gutun-azala (edizio honetako 49. gutuna).

39. Jatorrizko testuan: "deussic ecin / jrrisca desaqueguque unciguciiacarcen / tuste". Martin Arrundek Martin Arrunderi, Urruña, 1757/2/2, TNA, HCA 30/264, 114. gutun-azala (edizio honetako 1. gutuna).

40. Jatorrizko testuan: "Eta martin gazte cor-/ xurata goan Eta presan heldudela / anguellesec harturic plemuanda". Martin Durruitzek Domingo Durruitzi, Sara, 1757/3/2, TNA, HCA 30/264, 88. gutun-azala (edizio honetako 14. gutuna). 
Louisbourgi Zazpi Urteko Gerrak ekarriko zion azkenik hondamendia. Zazpi astez setiatua egon ondoren, gotorlekua ingelesen esku erori zen 1758ko uztailean. Ez zen hori britainiarrek hartuezina izateko fama zeukan gotorlekua setiatu eta harrapatu zuten lehen aldia. 1745ean, Ingalaterra Berritik etorritako 4.000 kolonoz osatutako armada batek zortzi aste behar izan zituen gotorlekua hartzeko. Frantziarentzat umiliazio galanta izan zen hura. 1749an, gerra bukatu ondoren, britainiarrek Louisbourg berriro frantsesei itzuli zieten. Orduan, 1745koa berriro gerta ez zedin, gotorlekuaren defentsa ahalmena hobetzeko lanak hasi zituzten. Baina 1758ko uda hasieran argi geratu zen hobekuntzok ez zirela nahikoa etsai boteretsu bati eusteko (ikus 1. IRUDIA). Frantziarentzat hain toki estrategikoa zela ikusirik, oraingoan britainiarrek Louisbourgeko gotorlekua guztiz suntsitzea erabaki zuten. Soldadu frantsesak Ingalaterrara bidali zituzten gerra-preso bezala, eta biztanle zibilak aldiz Frantziara. ${ }^{41}$ Azkenik gerran Britainia Handia atera zen garaile eta Louisbourgen ez zen berriro komunitate euskaldunik kokatuko.

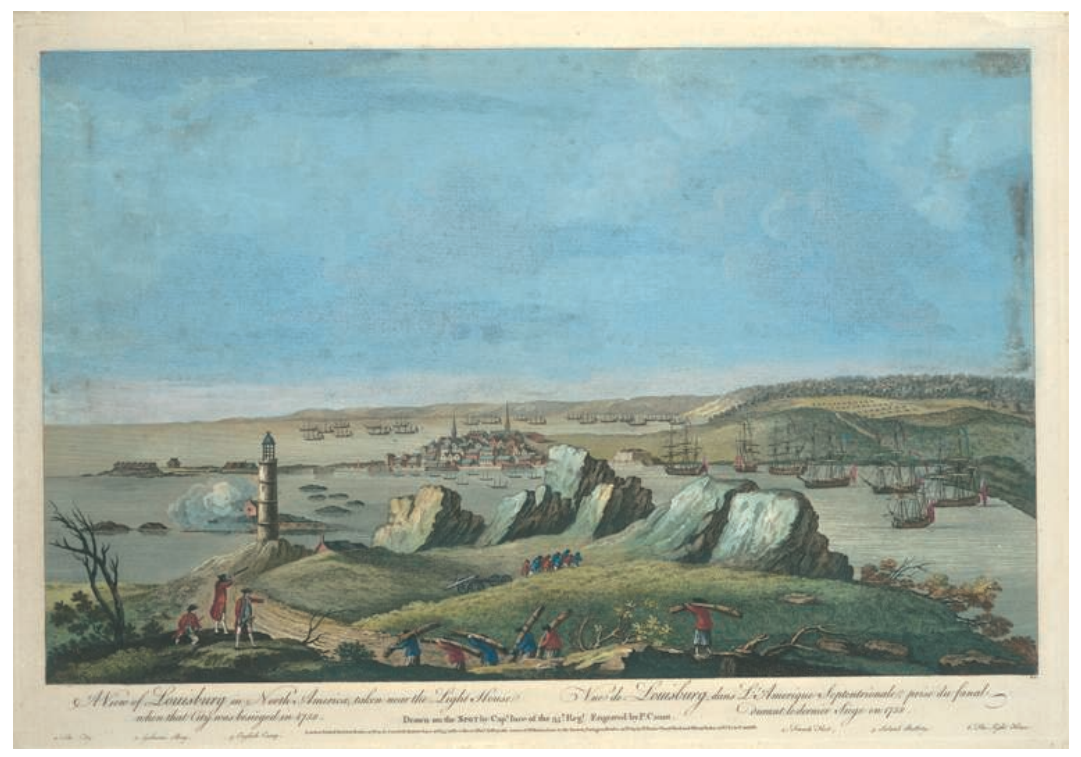

1. IRUDIA - "A View of Louisbourg in North America, taken near the Light House when that city was besieged in 1758" [Louisbourgen bista, Ipar Amerikan, itsasargi ondotik hartua 1758an hiria setiatua izan zenean], Londresen argitaratua 1762ko azaroan. Libraries and Archives Canada.

41. Moogk, Peter N., 2001, La Nouvelle France: The making of the French Canada, a cultural history, Michigan State University Press, East Lansing, 107-108. 


\section{Epilogo modura: euskara idatzia Mundu Atlantiarrean}

Le Dauphin-eko gutuneriarena oso aurkikuntza garrantzitsua da euskararen historiarako. XVIII. mendean herri xeheak euskara idatzia erabiltzen zuela susmatzen genuen, baina froga falta zen. Argi dago — gutuneriaren igorle eta hartzaile kopuruak ikustea besterik ez dago— Le Dauphin-ek erakusten duena ez dela salbuespen bat. Gutxienez Lapurdin, senide eta lagunei euskaraz idaztea praktika oso hedatua izan zen. Tamalez ez dugu inoiz jakingo, ezinezkoa delako, Atlantikoaren bestaldera beste zenbat euskarazko testu bidali ziren Aro Berrian zehar. Hala ere, horren ordez bada egin dezakegun beste zerbait: Le Dauphin-en paperak aurkitu genituen toki berean bilatu. Lan hori bukatu gabe dagoen arren, orain arte lortutako emaitzei buruz hitz bat edo beste esan nahi nuke. Baina lehenik, hain luzez ezezagunak zergatik izan diren ulertu ahal izateko, komeni da bahituak izan zirenetik eskutitzek Britainia Handian eta Britainia Handitik kanpo izan duten ibilbidearen berri ematea.

High Court of Admiralty-ren agiritegiko beste dokumentu guztiekin batera, Le Dauphineko eskutitzak Tower of London-en egon ziren 1856 arte. Orduan agiri gehienak dorretik atera eta Londreseko Chancery Lane kaleko Public Record Office-ren eraikinera eraman zituzten. Han egon ziren harik eta 1977an Londres hego-mendebaldeko PROren egoitza berrira tokialdatu zituzten arte. Egun han jarraitzen dute, Kew-ko auzoan. 2003az geroztik PROaren izena The National Archives da (www.nationalarchives.gov.uk).

Hogeita hamar urte inguru dira Kanadan Le Dauphin-eko eskutitzak ezagutzen dituztela, nahiz eta euskarazko materialari ez dioten ia kasurik egin. 1980ko hamarkada hasieran Eric Krausek (Fortress of Louisbourg National Historic Site of Canadako artxibozaina) Britainia Handiko agiritegietan Louisbourgekin lotura zuten agiriak mikrofilmatzeko proiektu bat jarri zuen abian. Bildutako agirien artean Le Dauphin-eko gutuneria osoa zegoen. Eskutitzok erabili zituen lehena John Bosher historialari kanadiarra izan zen, baina euskarazkoak alde batera utzi eta frantsesezkoak bakarrik aztertu zituen. ${ }^{42}$ Euskarazkoak erabili dituen kanadiar bakarra University of British Columbiako irakaslea den Peter Moogk izan da. Vancouverreko Maria Urquidi izeneko euskaldun baten (ziur aski bertako euskal etxeko kidea) laguntza jaso zuen Senpereko Martin Larraldek bere iloba Saint-Martin de Duronea kapitainari idatzitako lerroak itzultzeko. ${ }^{43}$ Hala ere, mende honetan argitaratu duen liburu batean Moogkek antza denez ahaztu egin du Duronea euskalduna zenik, historialari kanadiarra Duronearen sorterria Gaskoinia zela esatera mugatzen baita. ${ }^{44}$ Le Dauphin-eko eskutitzak erabili dituen azken historialari kanadiarra Anne Marie Lane Jonah izan da, 2010ean Parisen aurkeztutako hitzaldi batean; kasu horretan ere frantsesezko testuak izan ziren aztergai, ez euskarazkoak. ${ }^{45}$

Euskal Herrian duela urte gutxi izan genuen eskutitzon berri. Egia esan nik neuk aurkitu

42. Bosher, John F., 1987, The Canada Merchants, 1713-1763, Clarendon, Oxford.

43. Moogk, Peter N., 1989, "Reluctant exiles: Emigrants from France in Canada before 1760", William and Mary Quarterly 46:3, 486.

44. Moogk, La Nouvelle France, 138-139.

45. Lane Jonah, Anne M., "Lost Letters, Last Words", French Colonial Historical Society's Annual Meeting-ean aurkeztutako lana (Paris, 2010). 
nituen halabeharrez Londreseko agiritegian doktore tesirako lanean ari nintzenean. 2003an izan zen hori. Orduan aurkikuntza bitxi bat besterik ez zela pentsatu nuen, nire ikerketa gaiarekin loturarik ez zeukana, gainera. Agirien kutxaren erreferentzia idatzi eta doktore tesirako behar nituen agiriekin lanean jarraitu nuen. Gauza hor geratu zen harik eta 2007ko udazkenean Baionako IKEReko ikerlariekin kontaktuan jarri nintzen arte. Harri eta zur utzi nituen Le Dauphin-en berri eman nienean, eta harri eta zur utzi ninduten aurkikuntzaren garrantzia azaldu zidatenean. Gerora taldean aritu gara lanean eta Londresera zenbait bidai egin ditugu, Le Dauphin-eko eskutitzak aztertzera eta euskarazko korrespondentzia gehiago bilatzera. 1757ko eskutitzen azterketaren lehen emaitzak Gasteizen aurkeztu genituen 2012ko urrian. ${ }^{46}$

Le Dauphin-en berri izateko bi mende eta erdi behar izan baditugu hein handi batean Londreseko agiritegiaren errua izan da. Azken hamar urteetan katalogatzean hobekuntza nabarmenak egin badituzte ere, HCAko agirien katalogoak gabezia handiak izaten jarraitzen du. Izan ere, ikerlariak agiriak gordeta dauden kutxak (milaka kutxa!) banan-banan arakatu behar ditu barruan zer dagoen ikusteko, eta, askotan, aurkitzen duena anabasa hutsa izaten da.

1700 eta 1815 bitartean Frantzia eta Britainia Handia 49 urtez egon ziren elkarren aurka borrokatzen. Bost gerra nagusi izan ziren guztira. Ezin esan, beraz, gerra salbuespen egoera bat izan zenik, ezta gutxiagorik ere. XVIII. mendeak aurrera egin ahala Britainia Handiak batik bat itsasoan lortu zituen garaipen entzutetsuenak. 1740an James Thompsonek Rule, Britannia! abesti abertzale ezagunari hitzak jarri zizkionean ez zen batere oker ibili; nolabait, hitzok etorkizunaren premonizio bihurtu ziren: Rule, Britannia! Britannia rule the waves ('Britainia Nagusi! Britainia olatuen nagusi'). Britainiarrek milaka ontzi harrapatu zituzten Espainiako Oinordetza Gerran hasi eta Gerra Napoleonikoak bukatu ziren arte. Egun harrapakinen agiri, korrespondentzia eta epaiketetako paperak HCAren bi atal nagusitan daude banatuta: HCA 30 ("intercepted mail") eta HCA 32 ("Court papers and ship papers"). Azpimarratu behar da, halere, normalean harrapakinen kapitainek ontzian zeramatzaten posta zorroak eta agiri gehienak itsasora botatzen zituztela etsaiak bahitu ez zitzan. Horregatik HCAra harrapakin batzuen agiriak eta korrespondentzia osoak iristen ziren bakarrik, egun guk azter ditzakegunak.

Azken urteotan Aro Berriko historialariak HCAan dauden milaka eta milaka eskutitzak erabiltzen hasi dira, eta bertan aurkitu izan dutena ez dago bakarrik Europako hizkuntzatan idatzia; badira ere armenierazko (edo, hobe esanda, Julfa Berriko armeniarren persa kutxuko dialektoa) eta arabierazko eskutitzak ere, britainiarrak Atlantikoan ez ezik mundu osoan zehar

46. Lamikiz, Xabier, Padilla Moyano, Manuel \& Videgain, Xarles, 2013, "Le Dauphin itsasuntziko euskarazko gutunak (1757): transkribapena eta korapiloak", in R. Gómez, Ricardo, J. Gorrochategui, J. Lakarra \& C. Mounole (arg.), 3rd Conference of the Luis Michelena Chair - Koldo Mitxelena Katedraren III. Biltzarra - III Congreso de la Cátedra Luis Michelena, UPV/EHU, Vitoria-Gasteiz, 261-278. 
ibili zirelako seinale. ${ }^{47}$ Nik neuk gaztelaniazko eskutitzak erabili izan ditut Espainia eta Hego Amerikako merkatarien arteko harremanak aztertzeko. ${ }^{48}$ Hala ere, badirudi Londresera ikerlari gehien bidaltzen ari direnak nederlandarrak direla. Herbeheretako Liburutegi Nazionalak Londresen egon zitezkeen neerlanderazko eskutitzen inbentarioa egiteko proiektu bat jarri zuen abian 2004an, Sailing Letters deritzona. Emaitza sekulakoa izan zen: holanderazko 38.000 inguru eskutitz omen daude Londresen! Aurkikuntza oparo horrek bultzatuta, Leideneko Unibertsitateak Letters as Loot deritzon ikerketa proiektua hasi zuen 2008ko irailean. ${ }^{49}$

Beraz, Le Dauphin-eko gutuneria aztertzearekin batera, argi geneukan burutu beharreko ikerketa osagarria zein zen: HCAko kutxa guztiak arakatu beharra zegoen euskarazko eskutitz gehiago dauden ikusteko. Gorago aipatu bezala, lan horren zati bat eginda dago, baina emaitzak ez dira espero genituenak bezain onak izan. HCA 30 ataleko kutxetan (jada gehienak aztertu ditugu) zenbait eskutitz azaldu dira, baina ez Le Dauphin-ekoa bezalako eskutitz mordorik. HCA 32 atalean, ordea, hainbat kutxa ditugu ikusteke, batik bat 1793-1815 epealdikoak, zeinak oso gaizki katalogatuta dauden. Hor azaldu ziren, adibidez, Passement bezala sinatzen zuen lapurtar baten euskarazko bost eskutitz mamitsu, 1793ko martxoan La NouvelleOrléans-etik Hendaia eta Donibane Lohizunera bidaliak. ${ }^{50}$

Azken urteotako lana soilik harrapakin frantsesak aztertzera bideratu dugu. Horrek ez du esan nahi itsasontzi espainiarrak (Hego Euskal Herrikoak barne) baztertu ditugunik, ezta gutxiagorik ere. Ez da ahaztu behar XVIII. mende bukaera arte Espainia Frantziaren aliatua eta, beraz, Britainia Handiaren etsaia izan zela. Ehundaka espainiar itsasontziren paperak daude Londresen. Kontua da nik horiek tesirako ikerketa egin nuen garaian aztertu nituela (gehienak behintzat), eta orduan (ez) aurkitutakotik atera daitekeen ondorioa nahikoa argia dela: Hego Euskal Herriko euskaldunek ez zuten euren eskutitzetan euskararik erabiltzen, ez bazen hitz solteren bat edo beste.

Le Dauphin-ekin aldera daitekeen adibide bat La Diligente litzateke, 160 tonako merkataritza itsasontzia, kortsu agiririk ez zeramana. Baionatik atera zen 1745eko uztailaren 15ean, Habana eta Martinikarako bandan. Baionako Jean Garders merkataria zen jabea, eta kapitaina eta marinel gehienak ere lapurtarrak ziren. Baina ontzia Habanara zihoanez, hots, Espainiaren kolonia, Donostiako hainbat familiak Venezuela aldean zituzten senideei eskutitzak bidaltzeko aprobetxatu zuten. Donostiarren senideak Caracasko Gipuzkoar Konpainiarentzat (1728-1785) egiten zuten lan Venezuelan. Noski, eskutitzak ez ziren hara

47. Ikus Aslanian, Sebouh, 2004, "Trade Diaspora versus Colonial State: Armenian Merchants, the English East India Company, and the High Court of Admiralty in London, 1748-1752", Diaspora, 13:1, 37-100; AsLanian, Sebouh, 2008, "«The Salt in a Merchant's Letter»: The Culture of Julfan Correspondence in the Indian Ocean and the Mediterranean", Journal of World History, 19:2, 127-188; Sood, Gagan D. S., 2007, "«Correspondence is equal to half a meeting»: The composition and comprehension of letters in eighteenth-century Islamic Eurasia", Journal of the Economic and Social History of the Orient, 50:2-3, 172-214.

48. Lamikiz, Xabier, 2010, Trade and trust in the eighteenth-century Atlantic world: Spanish merchants and their overseas networks, Boydell Press / Royal Historical Society, Woodbridge.

49. Ikus<http://hum.leiden.edu/research/letters-as-loot/press-information/press-information.html> 50. El Navarro (1793), TNA, HCA 32/789 (1), 190, 193, 194, 195 eta 400. eskutitzak. 
inoiz iritsi, zeren La Diligente Leviathan izeneko kortsu-ontzi britainiar batek harrapatu zuen. Britainiarrek Donostiatik Caracas, La Guaira eta Puerto Cabellora bidalitako 56 gutunazal bahitu zituzten. ${ }^{51}$ Beraz, hemen daukagu XVIII. mende erdialdeko familia gipuzkoar batzuk idatzitako Le Dauphin-ekoa bezalako eskutitz kopurua, euskaraz idazten zuten ala ez ikusteko aukera aparta. Tamalez eskutitz bat bera ere ez dago euskaraz idatzia. Hitz solte eta esaldi laburren bat besterik ez: agur agur, zurea beti, goraincis edo sure vioseco esposa señac estimazen zatuena, besteak beste.

Hego Amerikatik penintsulara bidalitako eskutitzen artean ere ez dago euskaraz idatzitakorik. Adibide esanguratsu bat 1779an Perutik Cádizerako bidean harrapatua izan zen La Perla ontzia da: 2.267 eskutitz zekartzan barruan. Legez, 1778ko urrira arte kolonietatik zetozen ontzi gehienak zuzenean Cádizeko badiara sartzera behartuta egon ziren, baina ondoren ere, jada monopoliorik gabe, espainiar merkataritza koloniala hein handi batean Andalusiako portutik bideratua izaten jarraitu zuen. Horregatik han ehundaka merkatari bizi ziren, Espainiar monarkia osotik eta atzerritik etorriak, eta merkatarion artean talde handiena euskaldunek osatzen zuten. La Perlak erakusten duenez, Cádizeko euskaldunek Perun zituzten kontaktuak batez ere euskaldunak ziren, askotan euren herri berekoak. ${ }^{52}$ Hala ere elkarri idazten zizkieten eskutitzetan ia ez da euskararik ageri, La Diligentekoak bezalako hitz edo esaldi laburren bat ez bada: 'agur', 'urrengo artean', 'adisquide maytea', 'gorainciac' edo 'zurea veti vezala adisquide', besteak beste.

Noski, euskara idatzirik ez azaltzeak ez du esan nahi euskararik erabiltzen ez zutenik, eta are gutxiago euskararik ez zekitenik. Egia esan Cádiz eta Ameriketako merkatari euskaldun gehienek oso gazterik emigratzen zuten euren jaioterrietatik, normalean hogei urte bete baino lehen. Halaber, ez zuten itsuan emigratzen, merkataria zen osaba edo senide baten deiari erantzunez baizik. Eta, hain gazte izanik, emigratzerakoan euretako asko ez ziren gai izaten gazteleraz ondo mintzatzeko. Luis José de Echevarría errenteriar gaztearen adibideak ezaugarri hori ezin hobeto erakusten du. Errenteriatik 1745eko urrian atera zen Cádizera joateko. Espainia Britainia Handiarekin gerran zegoenez, bidaia lurrez egin zuen Pedro de Arambarri kapitainaren laguntzaz. Cádizen beste errenteriar batekin elkartu zen, Juan Bautista de Lacoa, eta biek Buenos Aireserantza zihoan itsasontzi bat hartu zuten, han Luis Joséren osaba zen Pedro de Iribarren merkatariarekin elkartzeko asmoz. Baina Buenos Aireserako ontzia atera aurretik, gerraren ondorioz, Luis Josék eta Lacoak hamar hilabete pasa behar izan zituzten Cádizen itxaroten. Tarte horretan Errenteriatik bidalitako hamalau eskutitz jaso zituzten, guztiak gazteleraz idatziak. Hala ere, horietako batean, Errenteriako osabak Juan Bautista de Lacoari ondoko esaldia Luis José gazteari irakurtzeko eskatu zion: "esaisu ea esten acordasen neregatic eta señoragatic eta besteacatic, baraqui senbat obligaci[o] badu don Luis jaunari, [eta] suc gure echeco gusiai". ${ }^{53}$ Eta esaldi horren jarraian zera gaineratu zuen: "Hermano Juan Bauptista, Michaela, la madre de Luis, mea echo escrivir lo de arriba para que se lo leas y le des

51. La Diligente (1745), TNA, HCA 32/104 (2). Ontziaren paperen artean Baionatik Martinikara bidalitako 16 gutun-azal ere daude, guztiak frantsesezko eskutitzekin.

52. Lamikiz, Trade and Trust, 100-107.

53. Ibid, 124. 
a entender bien bien bien". ${ }^{44}$ Euskarazko esaldi bat besterik ez, baina oso esanguratsua.

Hego Euskal Herriko euskaran idatzitako bi eskutiz bakarrik aurkitu ditut HCAko iturrietan, biak oso antzekoak eta pertsona berari bidaliak, Gipuzkoako Getariako José de Segura kapitainari. Bi eskutitzak larruzko zorro txiki batean zeramatzan Segurak bere ontzia Buenos Airesetik zetorrela britainiarrek harrapatu zutenean. Batak 1796ko abuztuko data du, besteak 1797ko urrikoa. Bigarrenaren testu osoa hau da:

Nere coñado maytea: emen bisi guera familia bioc alcarren compañean alcarri guere aleguinean lagunduaz zure notisien esperasen correoa pasa ta correoaren beguira judioac Mesiasen etorreraren becela, orra nere semaren letra su satozen arte lecu on batera dirijiseco recibituco dituzu ysecorequin beste gucien partes memoriac eta nere partes laztan bat sure coñata Curuza, Francisco Aristondo. ${ }^{55}$

Bukaerako Francisco Aristondo hori eskutitza idatzi zuen pertsona da. Horretatik ondoriozta daiteke Curuza Mendizabalek, Seguraren koinatak, ziurrenik ez zekiela idazten.

HCAko iturrietan azaltzen diren euskarazko eskutitz apurrek Le Dauphin-eko gutuneriaren balioa handiagotu besterik ez dute egiten. Bagenekien Hegoaldeko eta Iparraldeko euskaldunek presentzia oso eraginkorra izan zutela Aro Berriko atlantiar ekonomian. Orain badakigu euskaldunek ez ezik euskara idatziak berak ere ozeanoa maiz zeharkatu zuela, eta azken urteotan hain arrakastatsu bihurtu den Historia atlantiarrean —estatubatuarrek bultzatutako Atlantic history delakoa— leku bat merezi duela. ${ }^{56}$

54. Ibid.

55. Maria Curuza Mendizabalek Jose de Segurari, Getaria, 1797/10/12, TNA, HCA 49/8 (1).

56. Historia atlantiarra Aro Berriko Mundu atlantiarra aztertzen duen historiaren arloa da. Premisa honetan oinarritzen da: 1500-1800 epealdian ozeanoa inguratzen duten kontinenteek —Ipar eta Hego Amerika, Europa eta Afrika- eremu kultural eta ekonomiko komun bat osatu zuten. Historia atlantiarraren nondik norakoak ezagutzeko ikus BAiLyn, Bernard, 2005, Atlantic History: Concept and contours, Harvard University Press, Cambridge, MA. Badirudi historialari frantsesek ez dutela Historia atlantiarra begi onez ikusten: VidAL, Cécile, 2006, "The reluctance of French historians to address Atlantic History", Southern Quarterly, 43:4 (ale berezia: Imagining the Atlantic World), 153-189. 


\section{Bibliografia}

Aslanian, Sebouh, 2004, "Trade Diaspora versus Colonial State: Armenian Merchants, the English East India Company, and the High Court of Admiralty in London, 1748-1752", Diaspora 13:1, 37-100.

_ 2008, "«The Salt in a Merchant's Letter»: The Culture of Julfan Correspondence in the Indian Ocean and the Mediterranean", Journal of World History 19:2, 127-188.

Bailyn, Bernard, 2005, Atlantic History: Concept and contours, Harvard University Press, Cambridge, MA.

BANKs, Kenneth J., 2002, Chasing empire across the sea: Communications and the state in the French Atlantic, 1713-1763, McGill Queen's University Press, Montreal.

Bosher, John Francis, 1975, "A fishing company of Louisbourg, Les Sables d'Olonne, and Paris: La societe du Baron d'Huart, 1750-1775”, French Historical Studies 9:2, 263-277.

_ 1987, The Canada Merchants, 1713-1763, Clarendon, Oxford.

__, 2003, "Laborde, Jean", in Dictionary of Canadian Biography Online, 4. liburukia, University of Toronto / Université Laval.

$<$ http://www.biographi.ca/en/bio/laborde_jean_4E.html>

BOUYER, Murielle, 2000, "L' aire de recrutement des gens de mer, par le commerce nantais au XVIIIe siècle", in G. Saupin (koord.), Le Pouvoir urbain dans l'Europe Atlantique du XVIe au XVIIIe siécle, Ouest Éditions, Nantes. 165-178.

Davis, Ralph, 2012 [1962], The rise of the English shipping industry in the seventeenth and eighteenth centuries, International Maritime Economic History Association, St. John's, Newfoundland.

Dull, Jonathan R., 2005, The French navy and the Seven Years' War, University of Nebraska Press, Lincoln.

GreER, Allan, 1977, The people of New France, University of Toronto Press, Toronto.

Johnston, Andrew J.B., 1996, Life and religion at Louisbourg, 1713-1758, McGill Queen's University Press, Montreal.

—, 2001, Control and order in French colonial Louisbourg, 1713-1758, Michigan State University Press, East Lansing.

Lamikiz, Xabier, 2008, "Basque ship captains as mariners and traders in the eighteenth century", International Journal of Maritime History 20:2, 81-109.

, 2010, Trade and trust in the eighteenth-century Atlantic world: Spanish merchants and their overseas networks, Boydell Press / Royal Historical Society, Woodbridge.

Lamikiz, Xabier, Padilla Moyano, Manuel \& Videgain, Xarles, 2013, "Le Dauphin itsasuntziko euskarazko gutunak (1757): transkribapena eta korapiloak", in R. Gómez, Ricardo, J. Gorrochategui, J. Lakarra \& C. Mounole (arg.), 3rd Conference of the Luis Michelena Chair - Koldo Mitxelena Katedraren III. Biltzarra - III Congreso de la Cátedra Luis Michelena, UPV/EHU, Vitoria-Gasteiz, 261-278.

Lane Jonah, Anne Marie, "Lost letters, last words", French Colonial Historical Society's Annual Meeting-ean aurkeztutako lana (Paris, 2010).

Le Goff, Timothy J.A., 2003, "Daccarrette, Michel (d. 1745)", in Dictionary of Canadian Biography Online, 3. liburukia, University of Toronto / Université Laval. <http://www. biographi.ca/en/bio/daccarrette_michel_1745_3E.html>

Moogk, Peter N., 1989, "Reluctant exiles: Emigrants from France in Canada before 1760", William and Mary Quarterly 46:3, 463-505. 
—, 2001, La Nouvelle France: The making of the French Canada, a cultural history, Michigan State University Press, East Lansing.

Moore, Christopher, 1977, "Merchant trade in Louisbourg, Île Royale" (master tesi argitaratu gabea), University of Ottawa.

Proulx, Gilles, 1984, Between France and New France: Life aboard the tall sailing ships, Dundurn Press, Toronto.

SooD, Gagan D.S., 2007, "«Correspondence is equal to half a meeting»: The composition and comprehension of letters in eighteenth-century Islamic Eurasia", Journal of the Economic and Social History of the Orient 50:2-3, 172-214.

StARKEY, David J., 1990, British privateering enterprise in the eighteenth century, University of Exeter Press, Exeter.

Turgeon, Laurier, 1982, "Pêches basques en Atlantique Nord (XVIIe - XVIIIe siècles): étude d'économie maritime" (doktore tesi argitaratu gabea), Université de Bordeaux III.

van Rossum, Matthias, van Voss, Lex H., von Lottum, Jelle \& Lucassen, Jan, 2010, "National and international labour markets for sailors in European, Atlantic and Asian waters, 1600-1850", in M. Fusaro \& A. Polónia (arg.), Maritime History as Global History, International Maritime Economic History Association, St. John's, Newfoundland. 4772.

VIDAL, Cécile, 2006, "The reluctance of French historians to address Atlantic History", Southern Quarterly 43:4 (ale berezia: Imagining the Atlantic World), 153-189.

Wall, Robert E., 1964, "Louisbourg, 1745”, New England Quarterly 37:1, 64-83. 